\title{
The Au-Hosting Minerals and Process of Formation of the Carlin-Type Bojitian Deposit, Southwestern China
}

\author{
Kai Hu, ${ }^{1}$ Moucheng Pan, ${ }^{1,2}$ Jian Cao, ${ }^{1}$ Yin Liu, ${ }^{1,3}$ and Shanchu Han ${ }^{1,4}$ \\ ${ }^{1}$ State Key Laboratory for Mineral Deposits Research, School of Earth Sciences and Engineering, Nanjing University, \\ Nanjing 210023, China \\ ${ }^{2}$ Institute of Karst Geology, Karst Dynamics Laboratory, Ministry of Land and Resources, \\ Chinese Academy of Geological Sciences, Guilin 541004, China \\ ${ }^{3}$ School of Geosciences, China University of Petroleum (East China), Qingdao 266580, China \\ ${ }^{4}$ Key Laboratory of Nuclear Resources and Environment, Ministry of Education, \\ College of Earth Sciences, East China Institute of Technology, Nanchang 330013, China
}

Correspondence should be addressed to Kai Hu; kaihu@nju.edu.cn

Received 26 February 2017; Accepted 24 May 2017; Published 9 July 2017

Academic Editor: Weidong Sun

Copyright (C) 2017 Kai Hu et al. This is an open access article distributed under the Creative Commons Attribution License, which permits unrestricted use, distribution, and reproduction in any medium, provided the original work is properly cited.

\begin{abstract}
The recently discovered middle-sized Bojitian Carlin-type Au deposit is located in southwestern Guizhou Province, China, near the well-known Shuiyindong super-large-sized deposit. To improve the understanding on this deposit, here we investigate the minerals that host $\mathrm{Au}$ and the occurrence of $\mathrm{Au}$ in the deposit, using a combination of microscopic work and electron probe microanalysis (EPMA). Based on the results, the formation of the deposit was addressed. Results indicate that the dominant minerals that host Au include arsenian pyrite and arsenopyrite. $\mathrm{Au}$ in the cores of zoned pyrite exists mainly as natural nanoscale $\mathrm{Au}\left(\mathrm{Au}^{0}\right)$, while $\mathrm{Au}$ in the rims exists mainly as solid solution $\mathrm{Au}\left(\mathrm{Au}^{+}\right)$, but it likely also exists in the rims as natural nanoscale Au. The framboidal, coarsegrained, and banded pyrite types contain both natural nanoscale $\mathrm{Au}^{0}$ and solid solution $\mathrm{Au}^{+}$. The arsenopyrite is of hydrothermal origin, and $\mathrm{Au}$ within the arsenopyrite exists as gold solution $\mathrm{Au}^{+}$. The Bojitian deposit was formed from As-bearing, $\mathrm{H}_{2} \mathrm{~S}$-rich, low-to-medium-temperature fluids that migrated along faults and other channels. Au that was already present in the strata or source beds migrated with the fluids in the form of $\mathrm{Au}(\mathrm{HS})^{-}$and ore-forming fluids were then formed in the reducing environment. The ore-forming fluids interacted with Fe-rich carbonates to form an abundance of Au-hosting arsenian sulfides.
\end{abstract}

\section{Introduction}

The Carlin-type Au model, named after the deposits developed along the Carlin Trend in Nevada, USA, is widely used in exploration since the discovery of mineralization in 1962 [1]. This type of deposit is responsible for the largest known $\mathrm{Au}$ deposits and is the subject of a wealth of scientific and technical investigations [2-4]. One of the most important characteristics of the Carlin-type gold deposit is the fact that $\mathrm{Au}$ almost always occurs as visible gold in association with sulfides [5]. Study on the Au-bearing minerals and the occurrence of $\mathrm{Au}$ in the sulfides is important as it provides information on the ore-forming process (Zhao et al., 2011; [6, 7]; Cook et al., 2013). Whereas some studies suggest that the occurrences of Au mainly occur as a solid solution $\left(\mathrm{Au}^{+}\right)$and/or nanoparticles of native gold $\left(\mathrm{Au}^{0}\right)$, other studies suggest that $\mathrm{Au}$ can appear as $\mathrm{Au}^{-}$and $\mathrm{Au}^{3+}$ in the crystal structure of the sulfide [8-11]. Notwithstanding, we also note that visible gold is observed in some Chinese gold deposits that are considered to belong to the Carlin-type [12].

In the 1970s, a Carlin-type deposit was discovered in southwestern Guizhou Province [13]. The deposit forms the main part of the renowned Dian-Qian-Gui Au ore district, and the other ores in this district include those in the nearby Yunnan and Guangxi provinces [14, 15]. Recent ore exploration in this area has resulted in a number of significant findings, including the Shuiyindong super-large deposit, which has an average Au grade of $9.05 \mathrm{~g} / \mathrm{t}$ and 


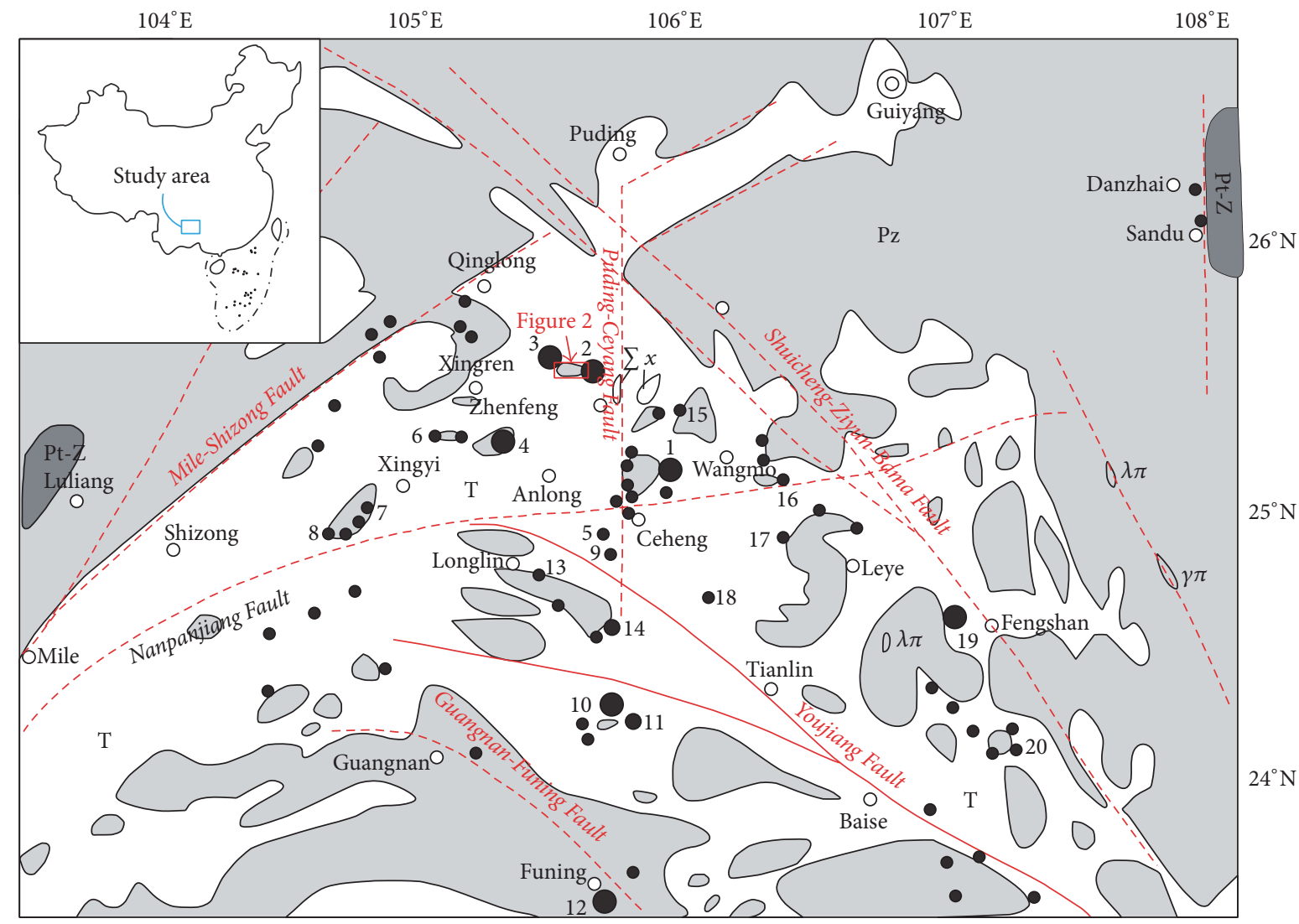

\begin{tabular}{|c|c|c|}
\hline $\mathrm{T}$ & $\mathrm{A}$ & $\sum x \mathrm{~F}$ \\
\hline $\mathrm{Pz}$ & $\mathrm{B}$ & \\
\hline $\mathrm{Pt}-\mathrm{Z}$ & $\mathrm{C}$ & $\mathrm{G}$ \\
\hline$\gamma \pi$ & $\mathrm{D}$ & $\bullet \bullet$ \\
\hline$\lambda \pi$ & $\mathrm{E}$ & $\mathrm{O}$ \\
\hline
\end{tabular}

FIGURE 1: Geological sketch map showing the occurrence of Carlin-type gold deposits in the Dian-Qian-Gui gold-rich district (modified after Su et al., 2002). A, Triassic; B, Paleozoic; C, Proterozoic; D, late Yanshanian granite porphyry; E, late Yanshanian quartz porphyry; F, late Yanshanian alkaline ultrabasic rock; G, fault; H, gold deposit; I, towns, including (1) Lannigou, (2) Shuiyindong, (3) Zimudang, (4) Getang, (5) Yata, (6) Nibao, (7) Xiongwu, (8) Lubuge, (9) Banqi, (10) Gaolong, (11) Badu, (12) Gedang, (13) Maxiong, (14) Longhuo, (15) Nage, (16) Lekang, (17) Langquan, (18) Baidi, (19) Jinya, and (20) Linbu.

a proven reserve of over $50 \mathrm{t}[16,17]$. One recently discovered $\mathrm{Au}$ deposit in this district, named the Bojitian deposit, is located close to Shuiyindong and has a proven $\mathrm{Au}$ reserve of $\sim 18 \mathrm{t}$. To date, there have been few studies of the Bojitian deposit because it has only recently been discovered, and the nature of the ore-forming process is poorly understood $[18,19]$.

Therefore, to improve our understanding of the Bojitian deposit, we have used electron probe microanalyses to investigate the Au-hosting minerals and the occurrence of Au. The results will contribute to our understanding of the general processes of ore formation in this district, as well as the origins of the Carlin-type gold deposits in South China.

\section{Geological Setting}

The Bojitian Au deposit occurs in the Dian-Qian-Gui Aurich district, which occurs in the Youjiang Basin at the southwestern margin of the Yangtz Craton (Figure 1). The basin is bordered by the regional Mile-Shizong deep fault in the northwest, the Nanpanjiang Fault in the south, and the Shuicheng-Ziyun-Bama Fault in the northeast [20-23]. Many Au ores and deposits have been found in this area (Figure 1).

The Bojitian Au deposit is tectonically located on the southwestern margin of the Yangtz Craton [20, 21]. The deposit is located in the eastern part of the Huijiabao anticline (Figure 2) and together with other ore deposits makes up the E-W-trending Huijiabao $\mathrm{Au}-(\mathrm{Hg})$ field (Figure 2) [24, 25].

Huijiabao is an important anticline, hosting eight $\mathrm{Au}$ deposits, five Ag deposits, and one Ag-Tl deposit. The renowned super-large Shuiyindong Carlin-type Au deposit and the large-sized Zimudang Au deposit are both hosted in this anticline. Devonian to Triassic strata are prominent in this area and have a total thickness of $>10,000 \mathrm{~m}$. Triassic strata occupy roughly two-thirds of the total area, and Permian 


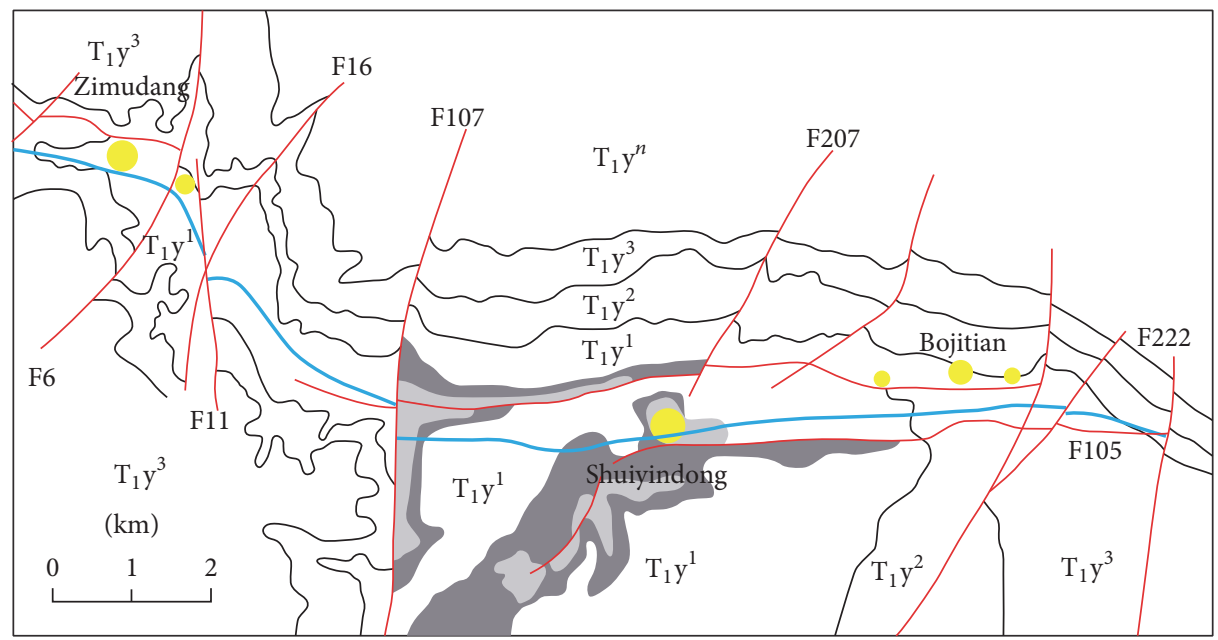

Lower Triassic

$\mathrm{T}_{1} \mathrm{y}^{n}$ Yongningzhen Formation

Yelang Formation

$\mathrm{T}_{1} \mathrm{y}^{3}$ Third unit

$\mathrm{T}_{1} \mathrm{y}^{2}$ Second unit

$\mathrm{T}_{1} \mathrm{y}^{1}$ First unit

Upper Permian

Changxing Formation
Longtan Formation

Third unit

Gold deposit

Fault

Axis of Huijiabao anticline

FIGURE 2: Geological sketch map of the Huijiabao gold field in southwestern Guizhou Province (modified after [40]).

strata are the second most important in terms of outcrop area. Carboniferous and Devonian strata are only exposed locally in the cores of several anticlines and domes (Figure 2). The main strata in the district, from bottom to top, are the middle Permian Maokou Formation $\left(\mathrm{P}_{2} \mathrm{~m}\right)$, the upper Permian Longtan $\left(\mathrm{P}_{3} \mathrm{l}\right)$ and Changxing (or equivalent Dalong) formations $\left(\mathrm{P}_{3}\right.$ ch or $\left.\mathrm{P}_{3} \mathrm{~d}\right)$, the Lower Triassic Yelang $\left(\mathrm{T}_{1} \mathrm{y}\right)$ and Yongningzhen $\left(\mathrm{T}_{1} \mathrm{y}^{n}\right)$ formations, and scattered Quaternary deposits. Magmatic rocks are found only to the NW, outside the mine area, and they consist of alkaline ultrabasic rocks and the Emeishan basalt [20, 26-28].

The dominant strata that host $\mathrm{Au}$ in the Bojitian deposit are the upper Permian Dachang layer, the Longtan Formation, and the first member of the Yelang Formation [18]. The Dachang layer is located along an unconformity between the Maokou and Longtan formations, and it commonly signals the presence of an altered rock association that formed during regional tectonism and hydrothermal activity [29]. The Maokou Formation consists predominantly of light-gray thick-layered bioclastic limestone. The Longtan Formation consists of gray layered siliceous limestone, calcareous clay rock, brecciated clay rock, siltstone, and fine sandstone. The Yelang Formation contains clay rock, siltstone, marl, limestone, and oolitic limestone.

Three structural trends can be recognized in the area (Figure 2): the NW-SE-trending Huijiabao anticline and reverse faults along the anticlinal axis and NE-SW and N-Strending anticlines, faults, and interlayer structures, such as the decollement between the lower Permian Maokou Formation and the upper Permian Longtan Formation. The surficial structures were formed during the Indosinian-Yanshanian orogeny, and the tectonic features are complex $[20,24,30]$. In general, the location of the Au deposits in this area is controlled by the E-W-trending Huijiabao anticline and to a lesser degree by E-W and N-S-trending faults [18].

The ore bodies of the Bojitian Au deposit can be divided into two types: strata-bound and fault-controlled, based on the occurrence, shape, and structure [31, 32]. The stratabound ore bodies are the dominant type, and they can be subdivided into carbonate and silicified breccia types based on the nature of the ore-bearing rocks. The layered and stratiform-like carbonate-type ore bodies are found within $300 \mathrm{~m}$ of the Huijiabao anticlinal axis. In contrast, the silicified breccia ore bodies are found in the Dachang layer, parallel to the plane of the unconformity. The fault-controlled ore bodies occur only in fracture zones that formed along a gently dipping reverse fault that produced a small displacement along the axis of the anticline [18,33].

These rocks contain a range of ore minerals, including pyrite, arsenopyrite, marcasite, realgar, orpiment, cinnabar, and stibnite. The gangue minerals are mainly calcite, dolomite, quartz, clay, and hydromica. These minerals form 


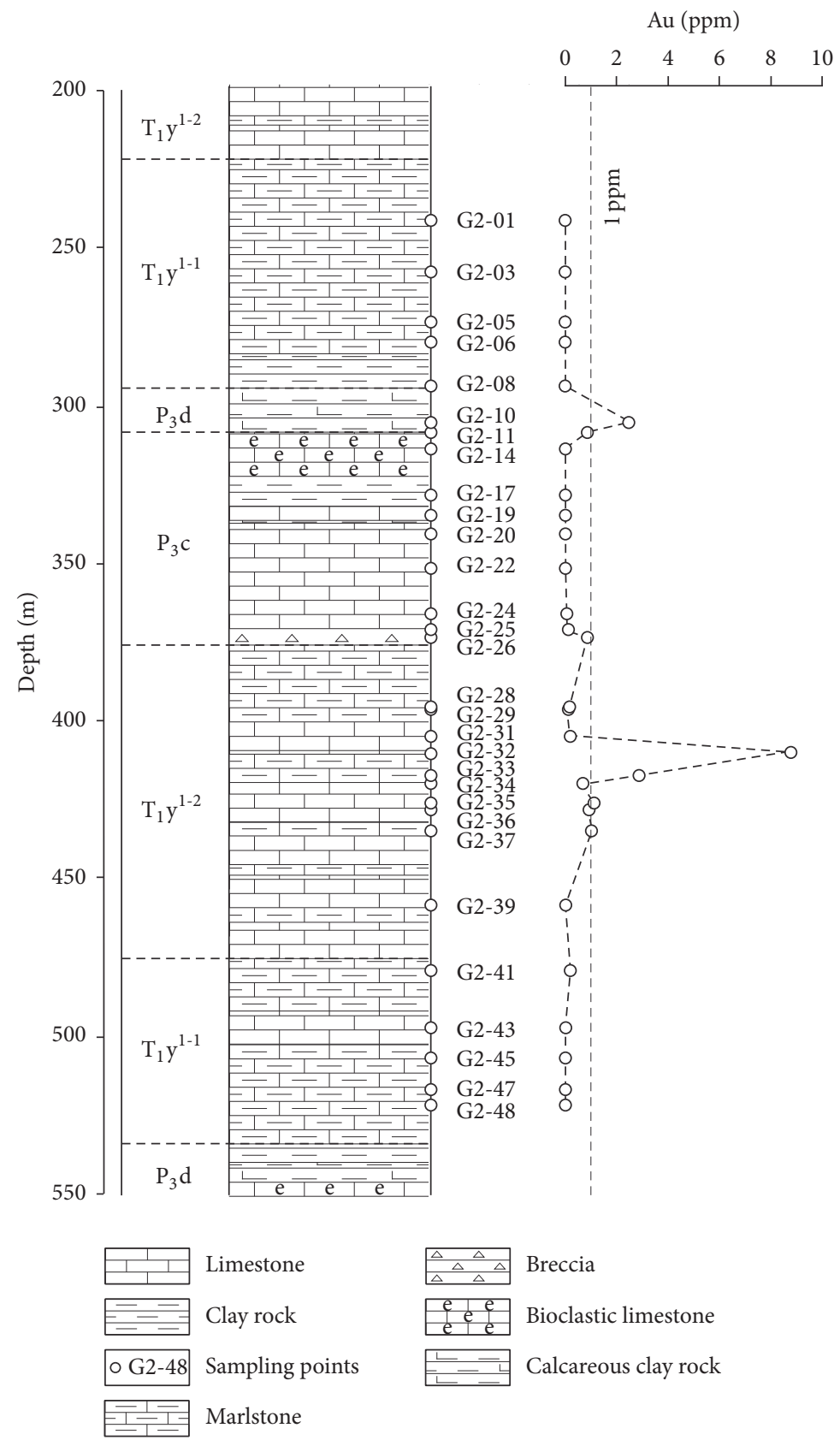

FIgURE 3: Generalized lithological column of well G2 in the Bojitian gold deposit.

various paragenetic associations, including quartz-dolomite, quartz-pyrite-arsenopyrite, quartz-calcite-realgar-orpimentstibnite-cinnabar, and pyrite-marcasite (Pan, 2012). Ore structures have multiple types, including disseminated, laminated, vein-like, lumpy, drusy, and brecciated. Ore textures are mainly euhedral and subhedral, framboidal, globular, metasomatic, and cataclastic.

Many types of hydrothermal alteration have been observed in the deposit, including silicification, dolomitization, pyritization, arsenopyrite mineralization, realgar (orpiment) mineralization, calcitization, stibnite mineralization, talc mineralization, fluorite mineralization, and cinnabarite mineralization. The $\mathrm{Au}$ mineralization seems to have a close relationship with the silicification, dolomitization, and pyritization $[28,30]$.

\section{Samples and Methods}

We collected 48 samples from depths of 243.00 to $522.90 \mathrm{~m}$ in well G2 (total depth $796.65 \mathrm{~m}$ ) (Figure 3). The samples were made into polished sections for observation under an optical microscope (Nikon E600POL). Thirty samples were then 
chosen for measurements of Au content (Table 1; Figure 3). Three samples (G2-10, G2-32, and G2-35) with relatively high Au contents $(2.54,8.71$, and $1.13 \mathrm{ppm}$, resp.) and different lithologies and occurrences were then chosen for further detailed electron probe microanalysis (EPMA). Five ore and 12 wall-rock samples were selected for trace element and REE analysis.

The contents of Au and trace elements were measured by ALS Chemex, Guangzhou, China. The Au analyses were conducted using the fire assay enrichment separation method and an atomic absorption spectrometer, with a detection limit of $0.005 \mathrm{ppm}$. The REEs and trace elements were detected by ICP-MS.

The EPMA analyses included backscattered electron (BSE) imaging and point analyses of minerals that host Au. Based on the EPMA results, representative minerals were chosen for elemental mapping (Au, As, S, and Fe). The EPMA analyses were conducted with a JEOL JXA-8100 instrument at the State Key Laboratory for Mineral Deposits Research of Nanjing University, China. The analyses employed an accelerating voltage of $15 \mathrm{kV}$, a beam current of $20 \mathrm{nA}$, and a beam width of $1 \mu \mathrm{m}$. Basic analytical conditions for EPMA are given in Table 2.

\section{Results}

4.1. Minerals That Host Au. The analytical results indicate that the main minerals that host Au in the Bojitian Au deposit are arsenian pyrite and arsenopyrite. This is also the case in the nearby Shuiyindong Au deposit and in other typical Carlin-type Au deposits worldwide [11,34-38]. Our analytical data and previous studies testified that the other minerals, such as quartz, calcite, clay, and carbonaceous, do not host $\mathrm{Au}$ in this deposit (Li and Ye et al., 2003 [19]).

\subsubsection{Arsenian Pyrite}

1. EPMA Backscattered Imaging and Point Analyses. The main types of arsenian pyrite in the present study are zoned pyrite and fine-grained pyrite, but we also observed framboidal, coarse-grained, and banded pyrite. In addition, some pyrite is present as filling in charcoal debris that forms a screen pipe or a conduit for plant rubble. The specific EPMA detection points and analytical results are given in Figure 4 and Table 3.

(a) Zoned Pyrite. The zoned pyrite is generally $10-30 \mu \mathrm{m}$ across, rarely over $50 \mu \mathrm{m}$. The grains all have single rims occurring as cubes and/or pentagonal dodecahedrons.

Sixteen points on zoned pyrite were chosen for EPMA analysis (points $z-1$ to $z-16$, Figure 4 ), with 8 points each in cores and rims. The cores commonly have relatively low contents of As and high contents of S and Fe (average contents of $0.06,53.66$ and 45.64 wt $\%$, resp.). We converted the EPMA analysis values to numbers of atoms and found that the Fe:S ratio is close to the theoretical value $(1: 2)$ of pyrite $\left(\mathrm{FeS}_{2}\right)$ (Table 4). Thus, we suggest that the cores of the zoned pyrite are typical pyrite. Au was detected in three of the eight core points at $0.03-0.05 \mathrm{wt} \%$, indicating that these cores contain
$\mathrm{Au}$. The average contents of other elements are $0.03 \mathrm{wt} \% \mathrm{Cu}$, 0.08 wt $\%$ Co, 0.02 wt $\% \mathrm{Ni}$, and $0.01 \mathrm{wt} \% \mathrm{Sb}$.

The elemental compositions of the rims of the zoned pyrite are quite different from the cores, being characterized by relatively high contents of As and low contents of $\mathrm{S}$ and Fe. The average As content in the rims is $6.60 \mathrm{wt} \%$, two orders of magnitude higher than that in the cores. The average rim contents of $S$ and Fe are $49.67 \mathrm{wt} \%$ and $43.36 \mathrm{wt} \%$, respectively; both values are lower than those in the cores. Calculation of the numbers of atoms suggests that the numbers of $S$ atoms in the rims are lower than that in the cores, but Fe atom numbers show little variation from core to rim. This result may indicate that some of the $S$ was replaced by As. The $\mathrm{Au}$ content in the rims varies from 0.07 to $0.10 \mathrm{wt} \%$, higher than that in the cores. The average contents of other elements in the rims are $0.23 \mathrm{wt} \% \mathrm{Cu}, 0.01 \mathrm{wt} \% \mathrm{Ag}$, 0.05 wt $\%$ Co, 0.02 wt $\%$ Ni, and 0.01 wt $\%$ Sb.

(b) Fine-Grained Pyrite. The fine-grained pyrite is smaller than the zoned pyrite, typically $<10 \mu \mathrm{m}$ across. This type of pyrite is disseminated, individual grains are unzoned, and the textures are homogeneous. Five points on fine-grained pyrite were chosen for EPMA analysis (points f-1 to f-5; Figure 4). The average contents of As, $\mathrm{S}$, and $\mathrm{Fe}$ are 7.28, 48.87, and $43.20 \mathrm{wt} \%$, respectively. Calculating the numbers of atoms shows that most of the Fe: $\mathrm{S}$ values in the fine-grained pyrite are lower than $1: 2$. The numbers of $\mathrm{Fe}$ atoms are relatively constant from core to rim, whereas the numbers of $S$ atoms are lower than in the cores and rims of the zoned pyrite. The numbers of As atoms are relatively high, indicating that some of the $\mathrm{S}$ was replaced by As. Au was detected at two points where the contents are $0.07 \mathrm{wt} \%$ and $0.14 \mathrm{wt} \%$, and clearly the fine-grained pyrite also hosts $\mathrm{Au}$. The average contents of other elements are $0.20 \mathrm{wt} \% \mathrm{Cu}, 0.05 \mathrm{wt} \% \mathrm{Co}, 0.03 \mathrm{wt} \%$ $\mathrm{Ni}$, and $0.01 \mathrm{wt} \% \mathrm{Sb}$. In general, the elemental compositions are similar to those in the rims of the zoned pyrite, reflecting relatively high $\mathrm{Au}$ and As contents and low $\mathrm{S}$ and Fe contents.

(c) Framboidal Pyrite. The framboidal pyrite grains are generally 5-20 $\mu \mathrm{m}$ across, rarely $25 \mu \mathrm{m}$. The framboidal pyrite occurs as disseminated single grains or aggregates. Three points on framboidal pyrite were analyzed (points fb-1 to $\mathrm{fb}-5$; Figure 4). The average contents of As, S, and Fe are $0.87,51.89$, and $44.39 \mathrm{wt} \%$, respectively. Calculations of the numbers of atoms show that the value of $\mathrm{Fe}: \mathrm{S}$ is close to the theoretical value $(1: 2)$ of pyrite (Table 4$)$. This indicates that the framboidal pyrite is typical pyrite. The framboidal pyrite contains $0.03-0.07 \mathrm{wt} \% \mathrm{Au}$, suggesting that some of this pyrite is rich in Au; however, it is not the main type of pyrite that hosts $\mathrm{Au}$. The average contents of other elements are 0.03 wt $\% \mathrm{Cu}, 0.01 \mathrm{wt} \% \mathrm{Ag}, 0.33 \mathrm{wt} \% \mathrm{Co}, 0.06 \mathrm{wt} \% \mathrm{Ni}$, and $0.03 \mathrm{wt} \% \mathrm{Sb}$. The elemental compositions of the framboidal pyrite are generally similar to those in the cores of the zoned pyrite, being characterized by relatively low contents of $\mathrm{Au}$ and As and high $\mathrm{S}$ and Fe.

(d) Coarse-Grained Pyrite. The coarse-grained pyrite is generally $50-300 \mu \mathrm{m}$ across, and it is unzoned. Four points on the coarse-grained pyrite were chosen for EPMA analysis (points 


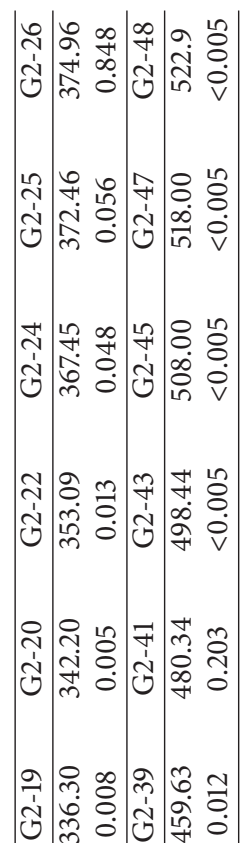

ㅇํㅇ

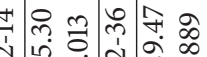

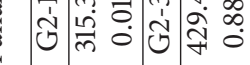

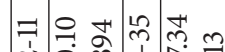

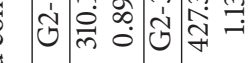
๑

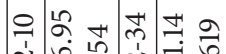
ป่

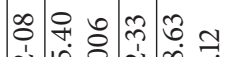
ป่̂

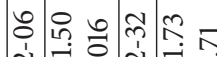
ป่

늉ํำ ปป

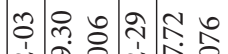
ป่̂

훙 ป่̂

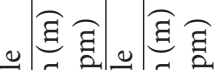

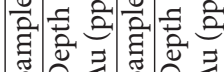


TABLE 2: Detection limits of EPMA analyses of minerals that host gold and that occur with gold.

\begin{tabular}{lccc}
\hline Elements & $\begin{array}{c}\text { Peak count } \\
\text { time }(\mathrm{s})\end{array}$ & $\begin{array}{c}\text { Background } \\
\text { count time }(\mathrm{s})\end{array}$ & $\begin{array}{c}\text { Detection limit } \\
\text { (wt.\%) }\end{array}$ \\
\hline $\mathrm{Au}$ & 40 & 20 & 0.03 \\
$\mathrm{As}$ & 30 & 15 & 0.02 \\
$\mathrm{~S}$ & 10 & 5 & 0.01 \\
$\mathrm{Fe}$ & 10 & 5 & 0.03 \\
$\mathrm{Se}$ & 30 & 15 & 0.02 \\
$\mathrm{Ag}$ & 30 & 15 & 0.01 \\
$\mathrm{Cu}$ & 10 & 5 & 0.05 \\
$\mathrm{Te}$ & 30 & 15 & 0.02 \\
$\mathrm{Co}$ & 40 & 20 & 0.03 \\
$\mathrm{~Pb}$ & 20 & 10 & 0.03 \\
$\mathrm{Ni}$ & 40 & 20 & 0.02 \\
$\mathrm{Bi}$ & 20 & 10 & 0.02 \\
$\mathrm{Zn}$ & 10 & 5 & 0.04 \\
$\mathrm{Sb}$ & 20 & 10 & 0.02 \\
\hline
\end{tabular}

c-1 to c-4; Figure 4), yielding average contents of As, S, and $\mathrm{Fe}$ of $4.76,49.88$, and $44.48 \mathrm{wt} \%$, respectively. Conversion to numbers of atoms indicates that the value of $\mathrm{Fe}: \mathrm{S}$ in the coarse-grained pyrite varies slightly around $1: 2$, implying that As may have replaced some of S. The Au contents are higher than the detection limit of $0.05-0.08 \mathrm{wt} \%$. Thus, the coarse-grained pyrite hosts $\mathrm{Au}$. The average contents of other elements are $0.11 \mathrm{wt} \% \mathrm{Cu}, 0.13 \mathrm{wt} \% \mathrm{Co}$, and $0.03 \mathrm{wt} \% \mathrm{Sb}$. The elemental compositions in the coarse-grained pyrite are similar to those in the rims of the zoned pyrite and in the fine-grained pyrite, with relatively high $\mathrm{Au}$ and As contents and low $\mathrm{S}$ and Fe.

(e) Banded Pyrite. Two points on banded pyrite were analyzed (points b-1 and b-2; Figure 3). The average contents of the three main elements, As, S, and Fe are 0.38, 52.38, and $45.52 \mathrm{wt} \%$, respectively. The conversion to numbers of atoms shows that the value of $\mathrm{Fe}: \mathrm{S}$ is close to $1: 2$. One of the two points contains relatively low amounts of $\mathrm{Au}(0.03 \mathrm{wt} \%)$, indicating that the banded pyrite is not the main host of Au. The average contents of other elements in the banded pyrite are 0.08 wt $\%$ Co, 0.10 wt $\% \mathrm{Ni}$, and $0.04 \mathrm{wt} \% \mathrm{Sb}$. The elemental compositions are generally characterized by relatively low As and Au contents and high S and Fe.

(f) Pyrite in Charcoal Debris. The charcoal debris (point cd1; Figure 4) was formed by a plant screen or by rubble in a conduit, and pyrite fills holes in the debris. The average contents of the three main elements As, $\mathrm{S}$, and Fe in this pyrite are $5.87,50.72$, and $43.53 \mathrm{wt} \%$, respectively. The Fe: $\mathrm{S}$ value is $1: 2.03$, close to the theoretical value $(1: 2)$ of pyrite. Thus, the charcoal debris pyrite appears to be normal pyrite. The $\mathrm{Au}$ content at the analytical point is lower than the detection limit, indicating that this pyrite is not one of the main Auhosting minerals. The average contents of other elements in this pyrite are $0.24 \mathrm{wt} \% \mathrm{Cu}$ and $0.03 \mathrm{wt} \% \mathrm{Co}$.
2. EPMA Mapping. To further understand the distribution of different elements in typical zoned pyrite, one sample (G210-03 with points $z-1$ and $z-2$ in Figure 4) was chosen for mapping the elements $\mathrm{Au}, \mathrm{As}, \mathrm{S}$, and Fe (Figure 5). The results further support the findings of the point analysis in general.

The distribution of $\mathrm{Au}$ does not show the predicted zonal structure, and there is instead a roughly heterogeneous distribution of light areas (Au-rich) and dark areas (less Au-rich) in Figure 5. However, the light areas are more concentrated in the rims of the zoned pyrite. Thus, while both the cores and rims of the zoned pyrite contain $\mathrm{Au}$, the $\mathrm{Au}$ contents of the rims are slightly higher than those of the cores. This finding is generally consistent with the results of the EPMA point analyses.

With respect to the distribution of As, the rims of the zoned pyrite show bright colors, while the cores show relatively dark colors in Figure 5. This reflects a much higher As content in the rims than in the cores. The distribution of $\mathrm{S}$ shows the opposite trend, with bright colors in the cores and less bright colors in the rims. In general, the distribution of $\mathrm{Fe}$ is similar to that of $\mathrm{S}$, but with a less obvious difference between rims and cores.

Overall, the above characteristics are similar to the results of the point analysis.

4.1.2. Arsenopyrite. In addition to arsenian pyrite, another Au-hosting mineral is arsenopyrite. Grains of arsenopyrite are $10-130 \mu \mathrm{m}$ long and $2-15 \mu \mathrm{m}$ wide. Eleven points on arsenopyrite were chosen for EPMA point analysis (Figure 6), and the analytical results (Table 5) indicate that the average contents of the three main elements, As, S, and Fe are $40.15,23.64$, and $34.97 \mathrm{wt} \%$, respectively. The conversion to numbers of atoms (Table 6) shows that the Fe: As: $\mathrm{S}$ ratio is not the theoretical value of $1: 1: 1$. The numbers of $A s$ and $\mathrm{S}$ atoms are approximately $1: 2$ in relation to Fe, implying that As has replaced some of $\mathrm{S}$. Au was detected at two points (0.09-0.122 wt\%; average $0.02 \mathrm{wt} \%)$. This indicates that the arsenopyrite is Au-hosting. The contents of $\mathrm{Au}$ in the arsenopyrite are commonly lower than in the rims of the zoned pyrite. The average contents of the other elements in the arsenopyrite are $0.02 \mathrm{wt} \% \mathrm{Cu}, 0.08 \mathrm{wt} \% \mathrm{Co}, 0.15 \mathrm{wt} \% \mathrm{Ni}$, and $0.01 \mathrm{wt} \% \mathrm{Sb}$.

The results of EPMA point analyses show that $\mathrm{Au}$ in the arsenopyrite exists as "invisible" ultramicroscopic packages of $\mathrm{Au}$ (nanoscale $\mathrm{Au}, \mathrm{Au}^{0}$ ) $[6,11]$. In agreement with previous studies, we infer that $\mathrm{Au}$ occurs in the arsenopyrite in a relatively simple way [38], and for this reason we did not undertake EPMA mapping of Au.

4.2. REEs and Trace Elements. The REE and trace element analyses were conducted on 17 samples from the ores and wall rocks of the Bojitian gold deposit (Table 7).

4.2.1. REEs. The total REE contents of the five ore samples vary from 100 to $269 \mathrm{ppm}$, with an average of $199 \mathrm{ppm}$. Chondrite-normalized REE patterns (normalizing values from [39]) are shown in Figure 8. It is showed that almost all the ore samples have similar REE patterns (Figure 8(a)), and 


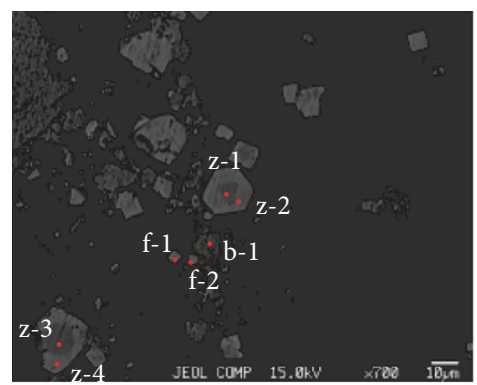

G2-10-03

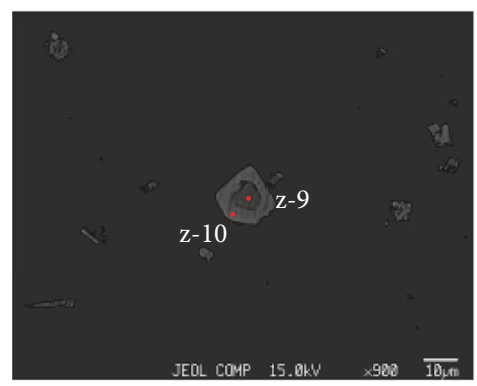

G2-10-10a

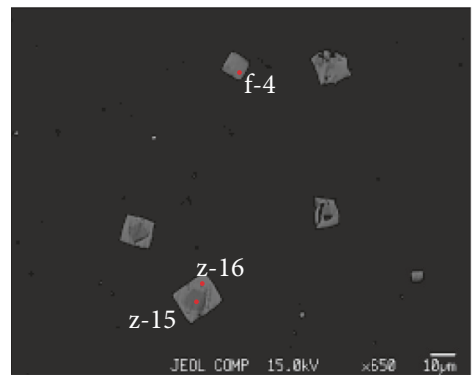

G2-32-09

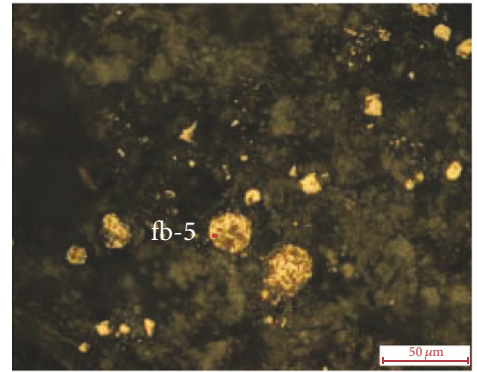

G2-32-08b

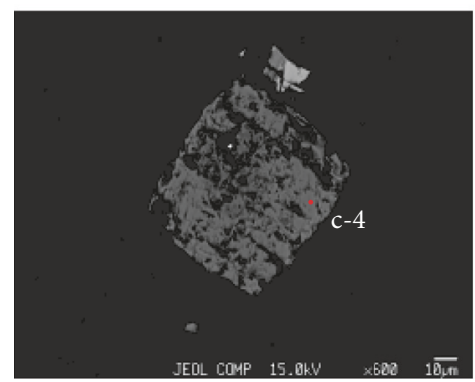

G2-32-03

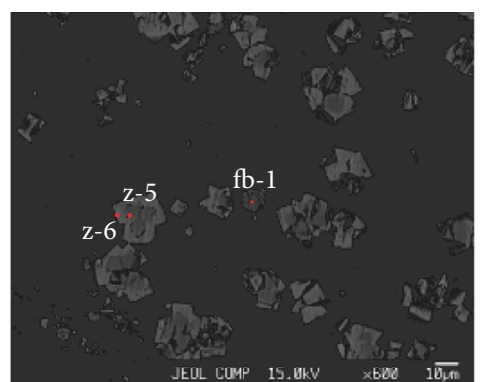

G2-10-05

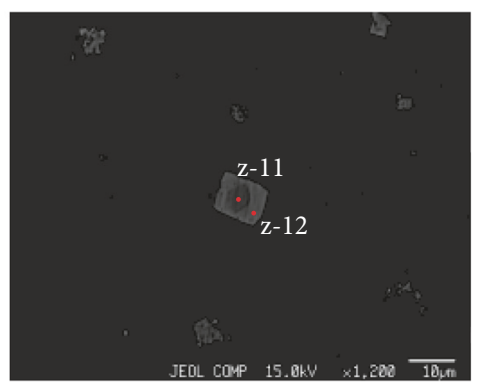

G2-10-10b

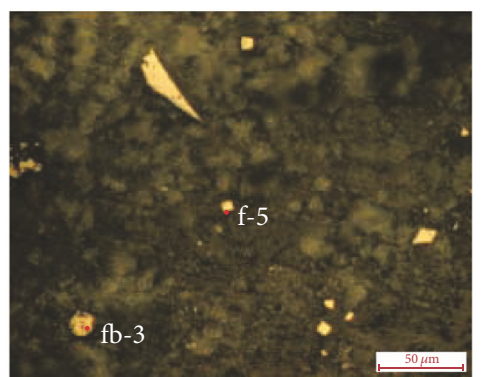

G2-35-02

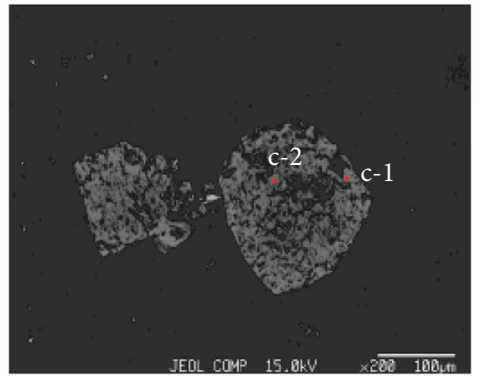

G2-32-06

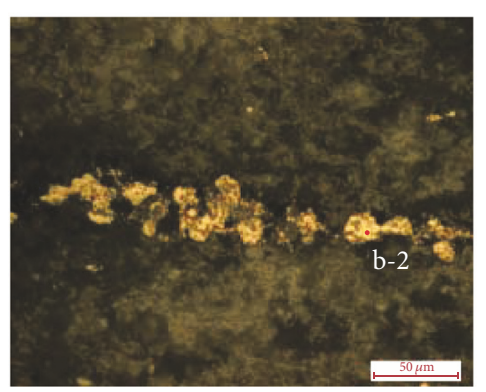

G2-32-11

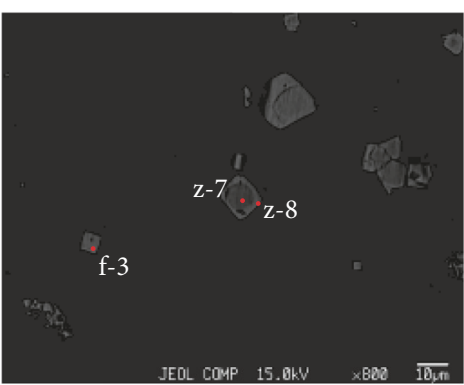

G2-10-09

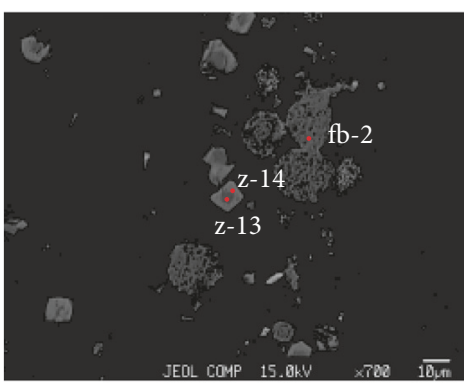

G2-32-08a

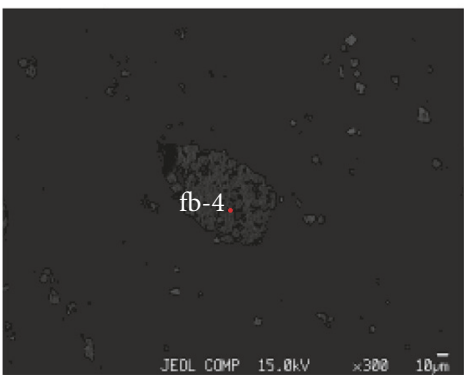

G2-10-02a

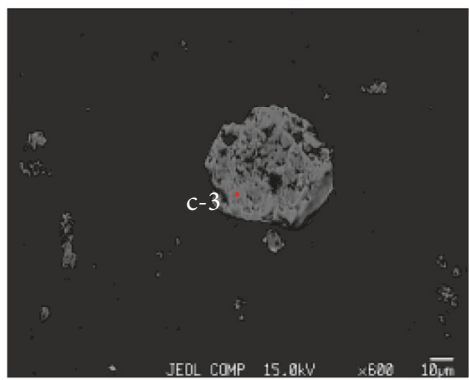

G2-32-04

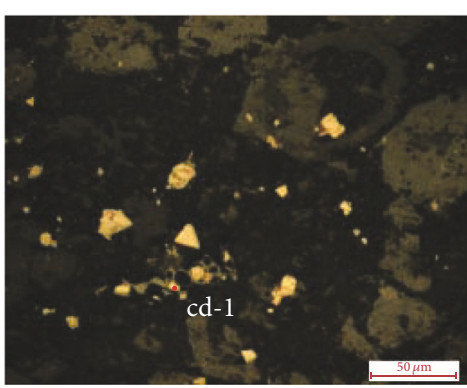

G2-10-02b

FIGURE 4: Microphotographs showing the structures of arsenian pyrite. EPMA analysis points are marked by red dots and the data are given in Table 3. The black-and-white images are EPMA BSE images, while the color images were taken under reflected light. Z, zoned pyrite; F, fine-grained pyrite; $\mathrm{C}$, coarse-grained pyrite; $\mathrm{B}$, banded pyrite; Fb, framboidal pyrite; and $\mathrm{Cd}$, charcoal debris pyrite. 


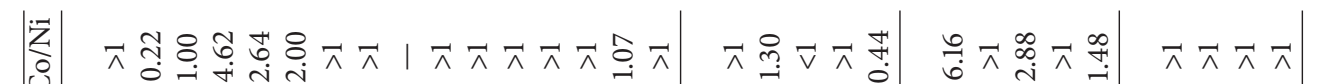

ঊ

웅

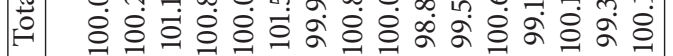

远官灾客

ํํํำ ำ

กิ่

๙

ลें

ज्ञ.

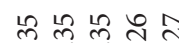

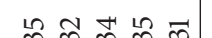

กิ กิ กิ

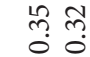

そ

ํํㅇ ํำ

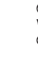

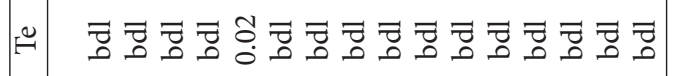

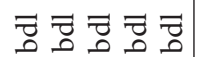

○

웅 눙

=

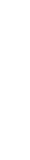

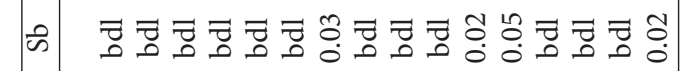

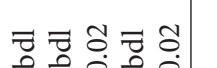

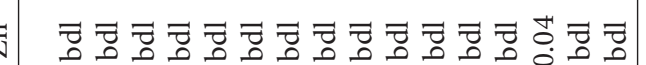

$\forall$ 우 우유

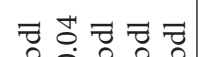

00000

西

웅 쿵 융 흉

กุ

$\stackrel{0}{\sharp}$

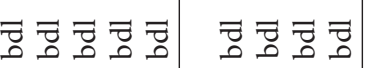

$\bar{z} \overline{8}$

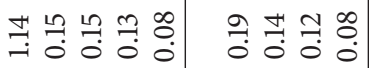

능응

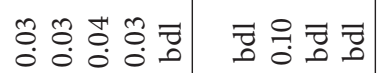

¿

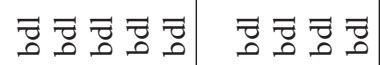

훙

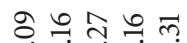

킁 킁 궁융 쿵

$\overline{7} \overline{8}$

2.

z

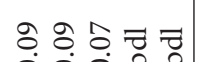

$\exists=7 \approx$

च సิ ‡ च

$\stackrel{0}{0}$

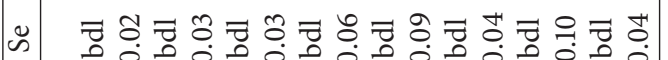

눙 $=7$ 눙

ఏे

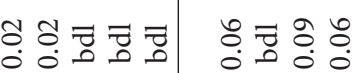

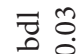

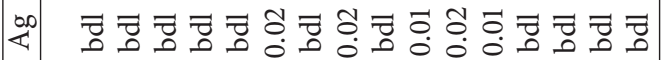

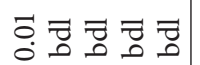

$\overline{7}$

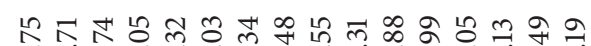

ㅈำส

ㅋํำ

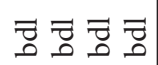

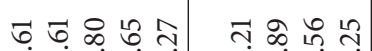

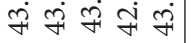

in

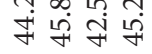

$\overline{0}:$

소욤유

늣ำ

8

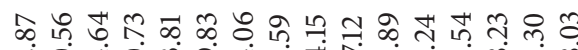

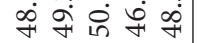

in in

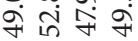

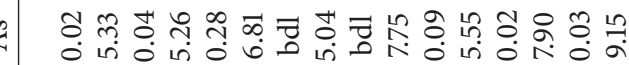

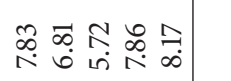

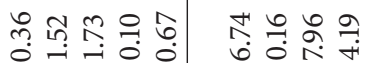

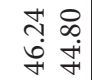

공ำ

玄

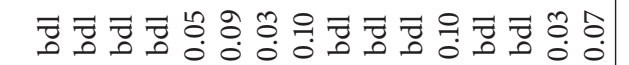

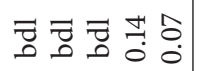

7

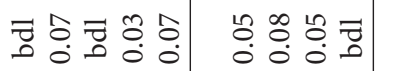

ํㅗㅇ

$\infty$
in
in

Iงก

IN

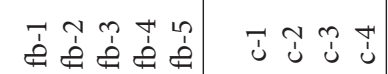

चृ

ซี
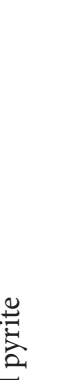

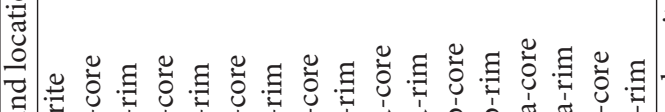

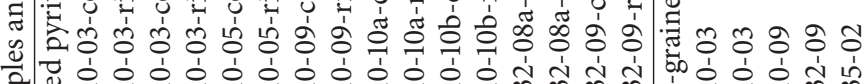
눈 


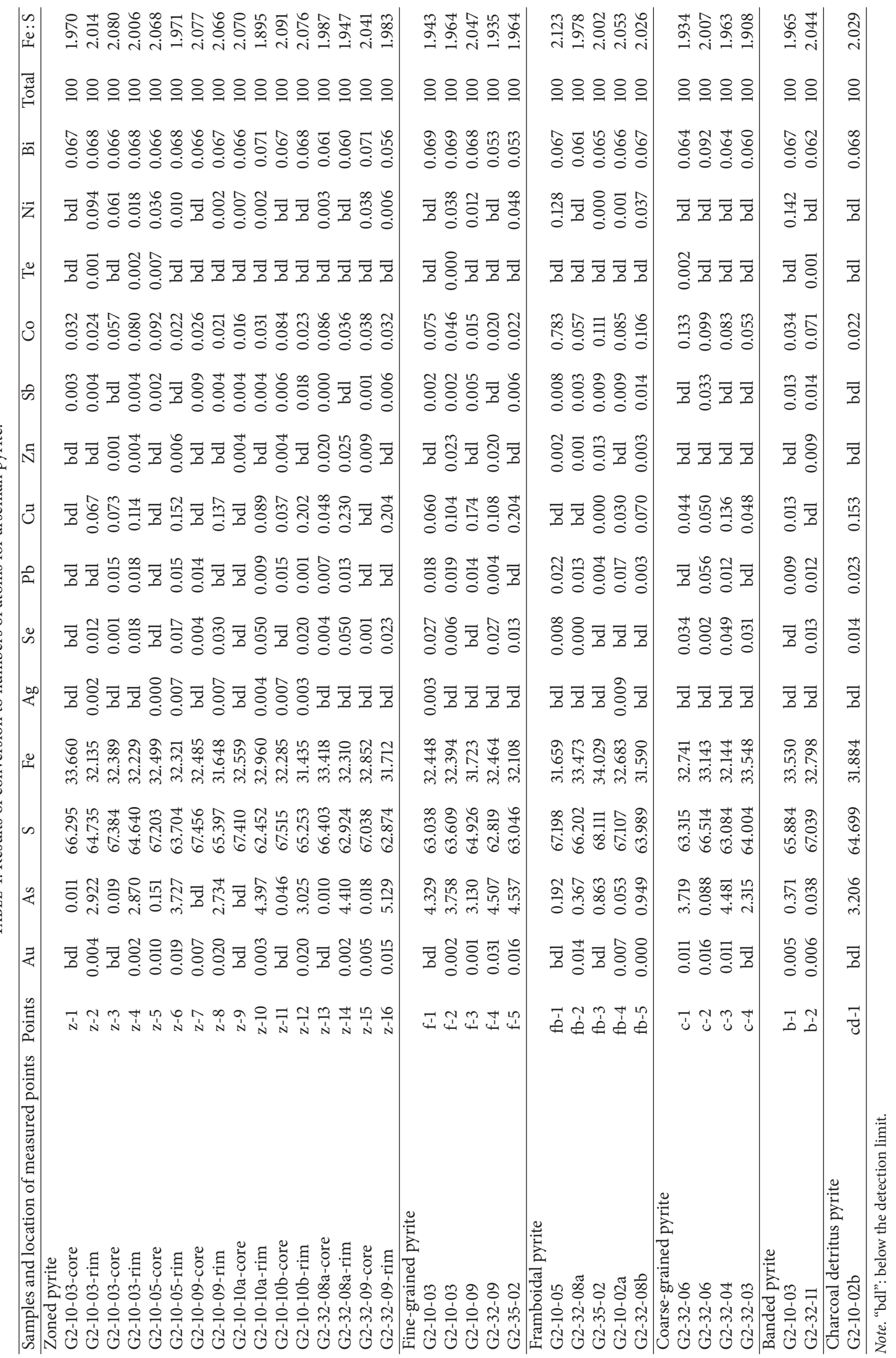




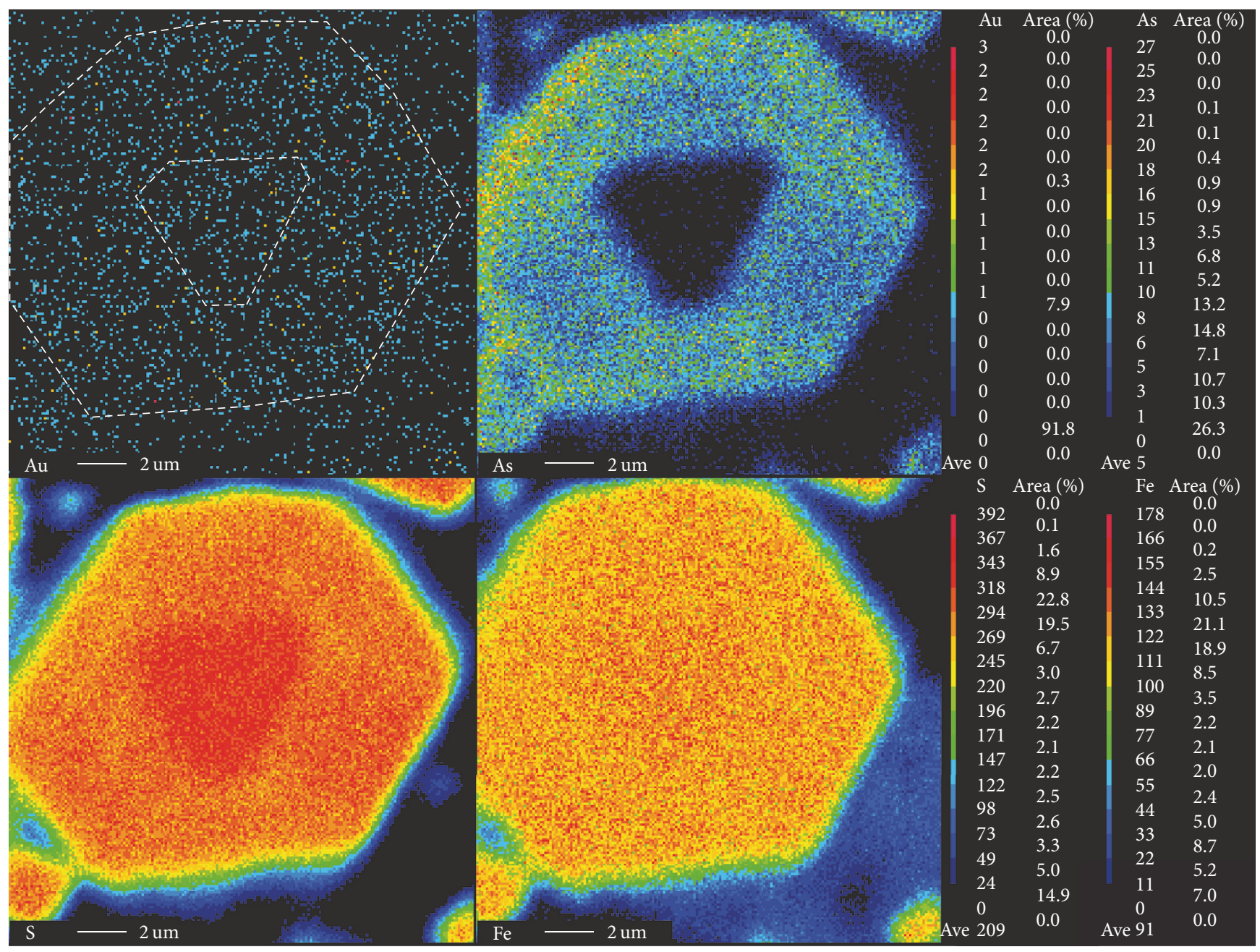

FIGURE 5: EPMA mapping of $\mathrm{Au}, \mathrm{As}, \mathrm{S}$, and $\mathrm{Fe}$ in arsenian pyrite showing their distribution in the pyrite.

they are enriched in the LREEs. The values of $\mathrm{La}_{\mathrm{N}} / \mathrm{Yb}_{\mathrm{N}}$ are 12.26-16.03, with an average of 13.49, and $\Sigma$ LREE/ $\Sigma \mathrm{HREE}$ ratios are 8.83-11.26, with an average of 9.77. Eu shows obvious negative anomalies, and $\delta$ Eu ranges from 0.75 to 0.89 (average $0.81)$. Ce shows no anomaly $(\delta \mathrm{Ce}=0.99-1.03$, average 1.00$)$.

Wall-rock samples have similar REE patterns (Figure $8(\mathrm{~b})$ ) to the ore samples (Figure $8(\mathrm{a})$ ). The total REE contents of the wall rocks are 50.9-322 ppm, with an average of $152 \mathrm{ppm}$. The LREEs are also enriched in the wall-rock samples, with $\Sigma$ LREE/ $\Sigma$ HREE ratios of 6.05 to 9.96 (average 8.79) and $\mathrm{La}_{\mathrm{N}} / \mathrm{Yb}_{\mathrm{N}}$ ranging from 8.46 to 14.92 (average 12.51). The wall rocks show slightly negative $\mathrm{Eu}$ anomalies, with $\delta \mathrm{Eu}=0.70-0.98$ (average 0.82 ). Some samples show slightly negative $\mathrm{Ce}$ anomalies, with $\delta \mathrm{Ce}$ ranging from 0.89 to 1.05 (average 0.98).

4.2.2. Trace Elements. To assess the degree of enrichment of trace elements in the ores and wall rocks, we normalized the data using average crust values (Rudnick and Fountain, 1995), and the crust-normalized curves are shown in Figures 8(c) and $8(\mathrm{~d})$. It is showed that all the samples are highly enriched in Sr and W (Figure 8(d)). The elements Cs, Nb, Sr, Ta, Tl, and
$\mathrm{W}$ are relatively enriched in the ore samples (Figure $8(\mathrm{c})$ ). In the wall-rock samples, $\mathrm{Cs}, \mathrm{Nb}$, and Ta show variable degrees of enrichment.

\section{Discussion}

5.1. Au-Hosting Minerals. The results indicate that arsenian pyrite and arsenopyrite are the main Au-hosting minerals in the Bojitian deposit. This is similar to the characteristics of the nearby Shuiyindong ultra-large Au deposit and other typical Carlin-type Au deposits worldwide $[2,6,40]$.

5.1.1. Arsenian Pyrite. The arsenian pyrite can be divided into six types, as discussed above (see Section 4.1). The zoned pyrites comprise cores and rims. According to the EPMA point analyses, the values of $\mathrm{Fe}: \mathrm{S}$ are close to the theoretical value of pyrite $(1: 2)$, indicating that the cores of the zoned pyrite are detrital in origin $[41,42]$. However, the values of $\mathrm{Co} / \mathrm{Ni}$ in the cores are generally higher than 1.0 , whereas the value of $\mathrm{Co} / \mathrm{Ni}$ in pyrite of clastic origin is usually less than 1.0 [43-46]. Therefore, the pyrite cores have probably been affected by hydrothermal activity. The fact that the pyrite 


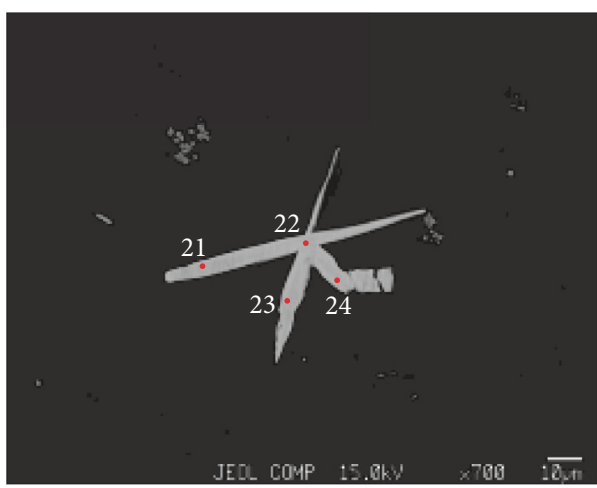

G2-32-01

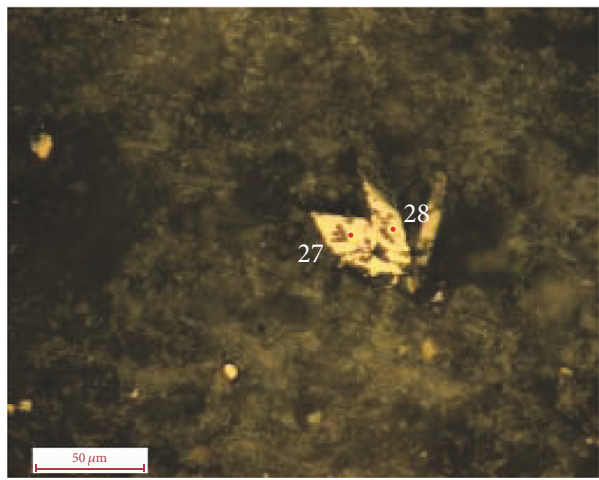

G2-32-05

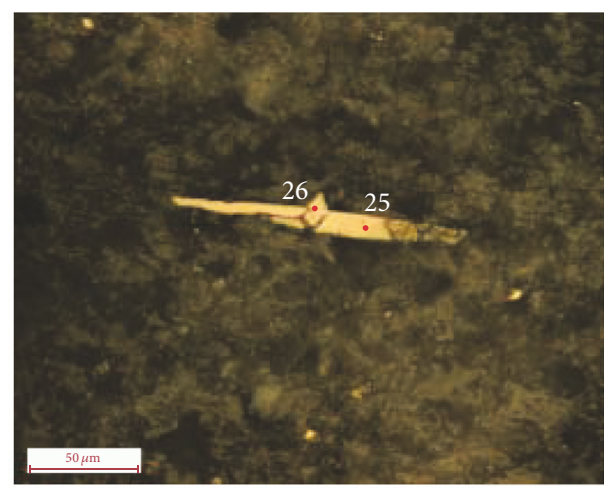

G2-32-02

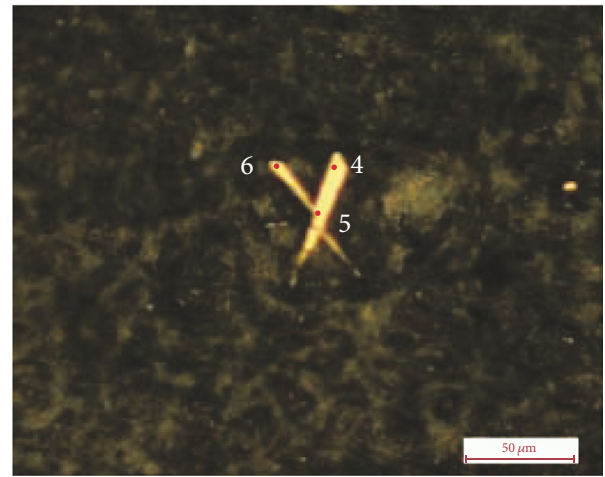

G2-35-01

FIGURE 6: Microphotographs showing the structures of arsenopyrite. EPMA analysis points are marked by red dots and the data are given in Table 3. The black-and-white images are EPMA BSE images, while the color images were taken under reflected light.

is much more abundant in the ore bodies than in the wall rocks also suggests that the pyrite has various origins, because a simple sedimentary origin may not have provided all the pyrite cores that now exist. Thus, the origin of the cores in the zoned pyrite is complex. The rims yield $\mathrm{Co} / \mathrm{Ni}$ values that are usually greater than 1.0, again suggesting a hydrothermal origin.

The other types of pyrite (i.e., the fine-grained, framboidal, coarse-grained, banded, and charcoal debris pyrite) have $\mathrm{Co} / \mathrm{Ni}$ values that are higher than 1.0 , also suggesting a hydrothermal origin or at least indicating the effects of hydrothermal activity. We conclude, therefore, that hydrothermal activity was commonplace during the period of ore formation.

5.1.2. Arsenopyrite. The arsenopyrite occurs mainly in ore samples from close to a hydrothermal channel (samples G232 and G2-35 from the $\mathrm{T}_{1} \mathrm{y}^{1-2}$ layer under the fault fracture zone; Figure 3). Only one generation of arsenopyrite was found, and the crystals are euhedral or subhedral and acicular or fibrous. In some cases the crystals form aggregates with a radiating pattern. EPMA analyses show that $\mathrm{Au}$ has a heterogeneous distribution, with local areas of enrichment. Generally, the Au content of the arsenopyrite is lower than that in the rims of the zoned pyrite.

5.1.3. Elemental Composition of Arsenian Pyrite and Arsenopyrite. Figure 7 shows the typical elemental compositions of the Au-hosting arsenian pyrite and arsenopyrite. The data show no obvious relationship between $\mathrm{Au}$ and Fe in either the arsenian pyrite or the arsenopyrite (Figure $7(\mathrm{a})$ ), but there is a negative correlation between As and S (Figure 7(b)) which suggests that the As in the structure of the arsenian pyrite has replaced $S[10,11,47]$. A similar negative correlation between As and S characterizes the arsenopyrite (Figure 7(b)). We found a relationship between $\mathrm{Au}$ and As contents in the arsenopyrite, although not a simple linear positive correlation as found for the arsenian pyrite (Figure $7(\mathrm{c})$ ). In general, the pyrite with a high content of As also has more Au. For example, the $\mathrm{Au}$ content of the As-rich rims of arsenian pyrite $(0.05 \mathrm{wt} \%)$ is roughly three times that of the cores (0.014 wt\%), which lack As. In contrast, there is no obvious correlation between $\mathrm{Au}$ and $\mathrm{As}$ in the arsenopyrite (Figure 7(c)), and the arsenopyrite with low and high As contents shows little difference in terms of hosting Au.

These results, in combination with the EPMA analyses, suggest that different types of sulfide can display different Au-hosting abilities. Overall, the Au contents of arsenian pyrite are slightly higher than those of arsenopyrite, and the Au-hosting ability within different types of arsenian pyrite follows the order of (from highest to lowest ability) zoned pyrite rims, fine-grained pyrite, coarse-grained pyrite, framboidal pyrite, banded pyrite, zoned pyrite cores, and pyrite in charcoal detritus. In general, there is a close relationship between $\mathrm{Au}$ and As content. The zoned pyrite and finegrained pyrite are the two main Au-hosting minerals, and the 


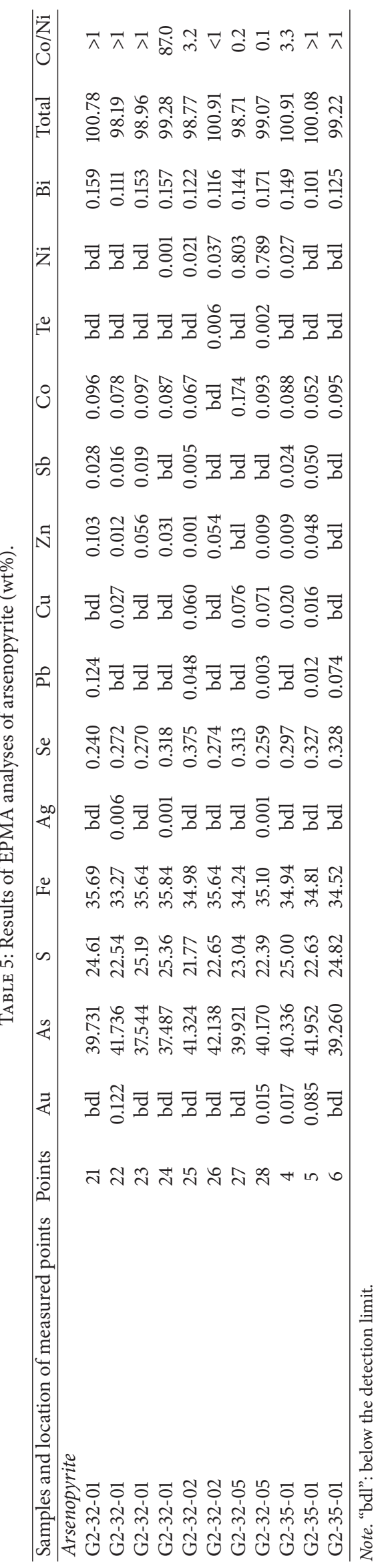




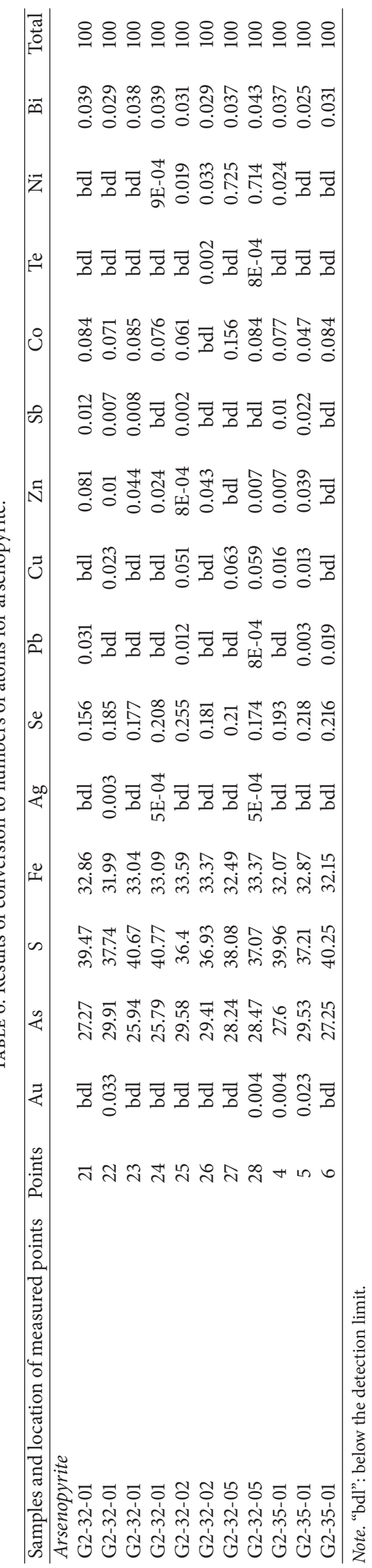




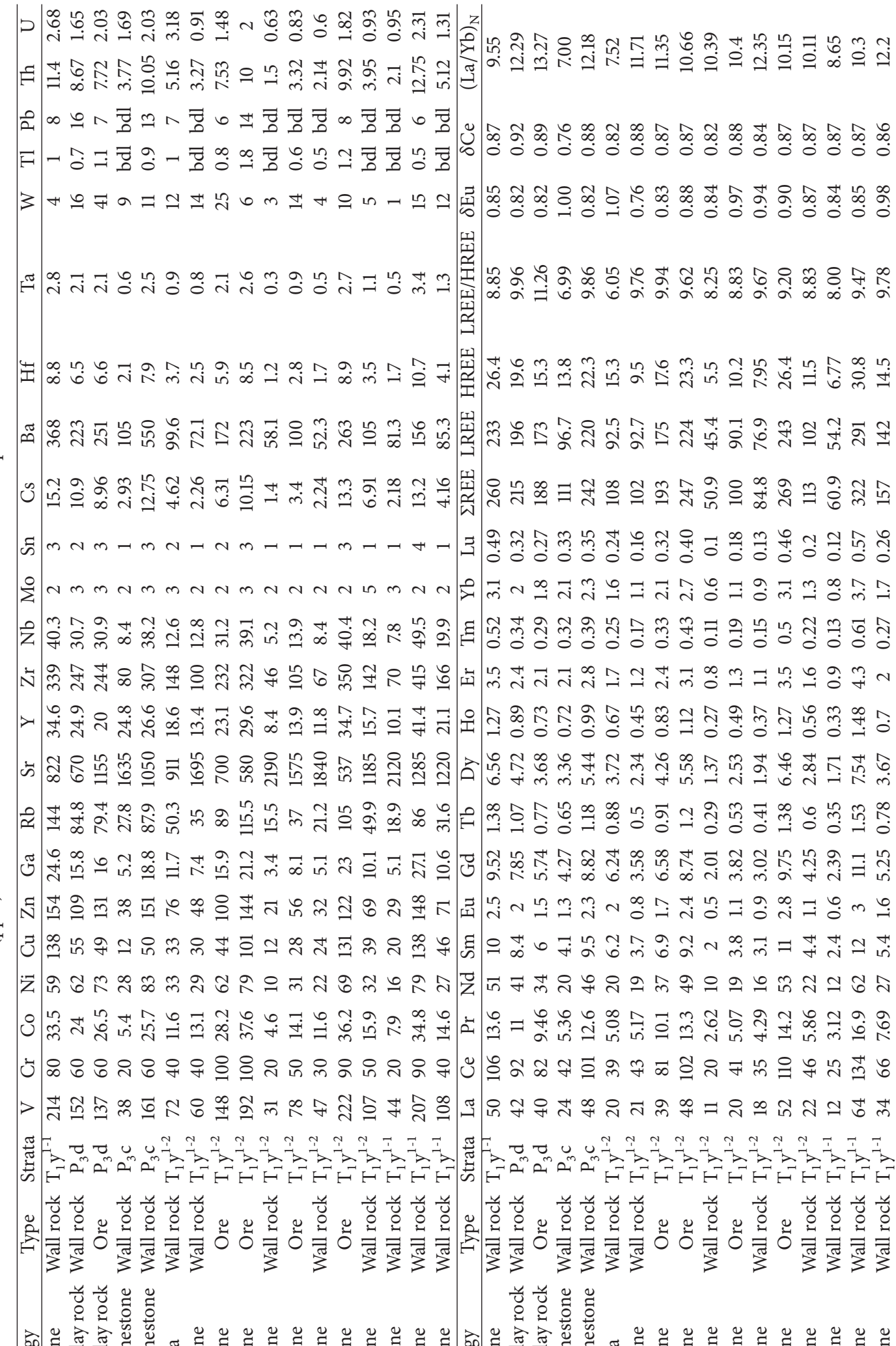

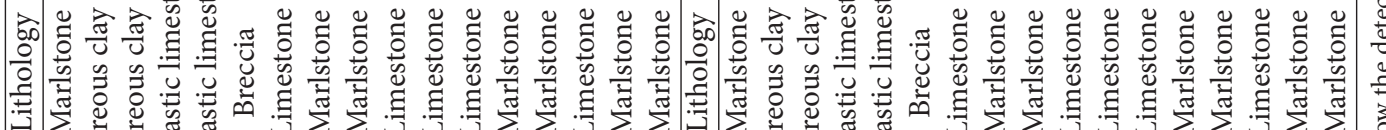

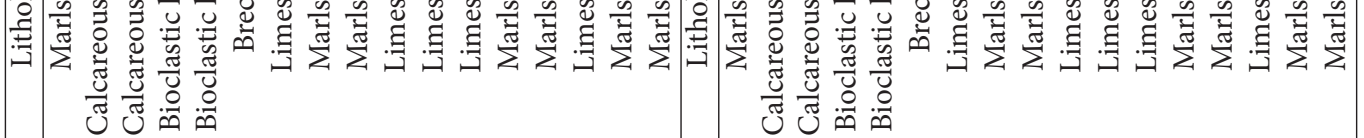

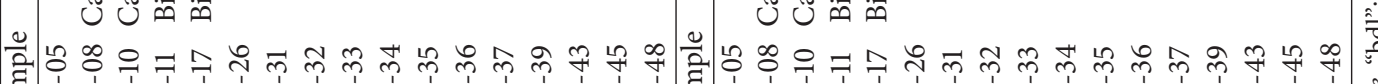
क्ञ 

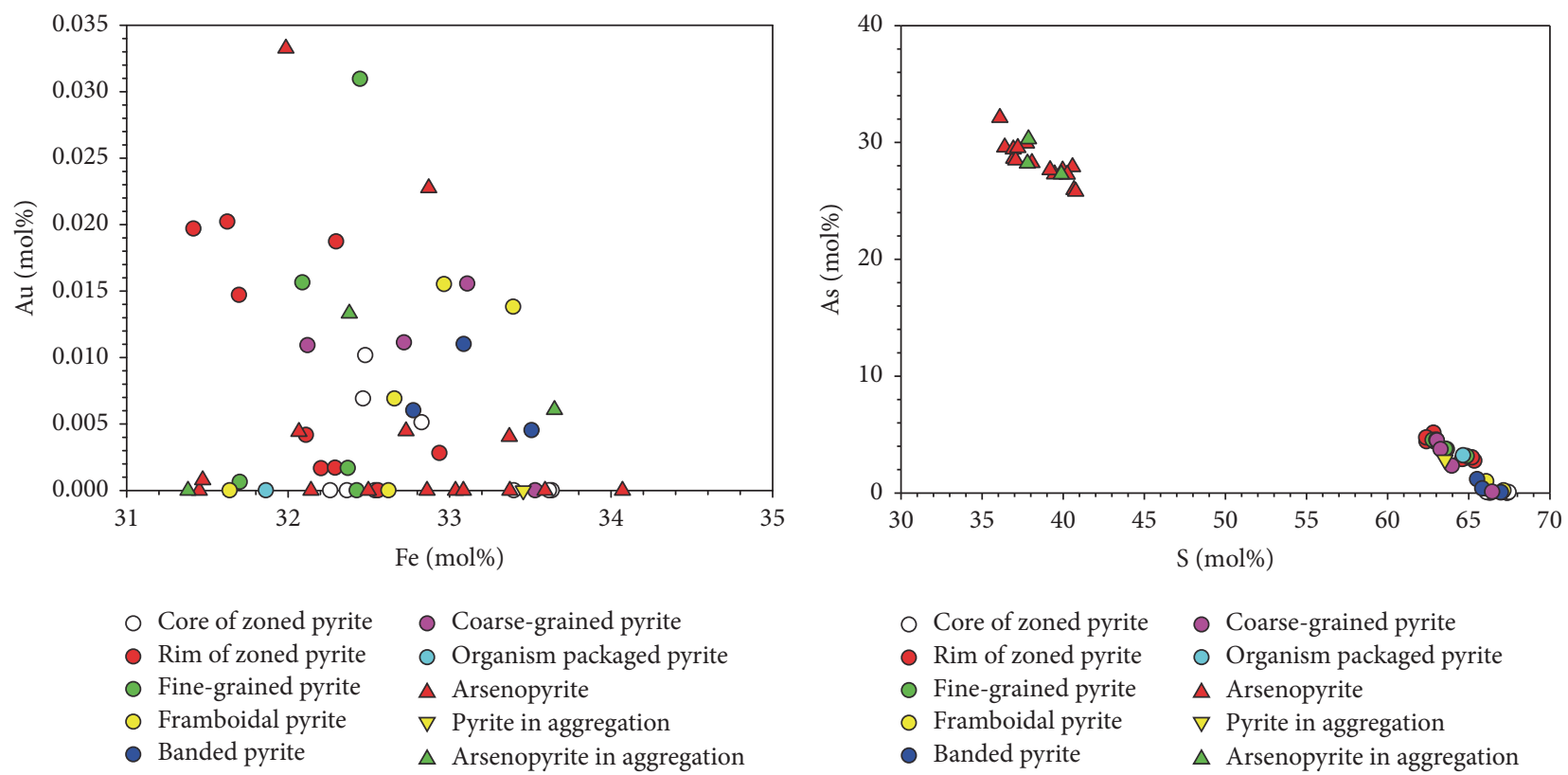

(a)

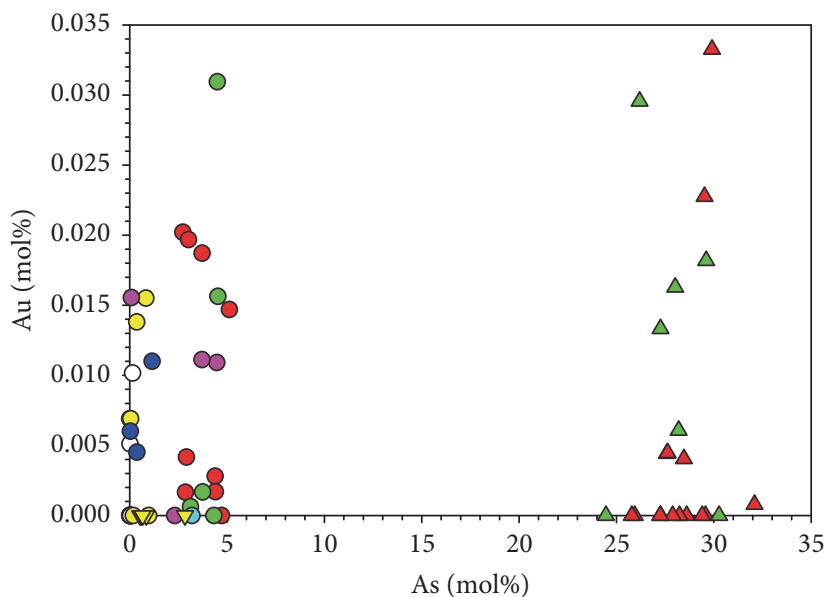

O Core of zoned pyrite

- Rim of zoned pyrite

- Fine-grained pyrite

O Framboidal pyrite

- Banded pyrite
- Coarse-grained pyrite

- Organism packaged pyrite

$\Delta$ Arsenopyrite

$\nabla$ Pyrite in aggregation

$\Delta$ Arsenopyrite in aggregation
- Coarse-grained pyrite

- Organism packaged pyrite

$\Delta$ Arsenopyrite

$\nabla$ Pyrite in aggregation

$\Delta$ Arsenopyrite in aggregation

(c)

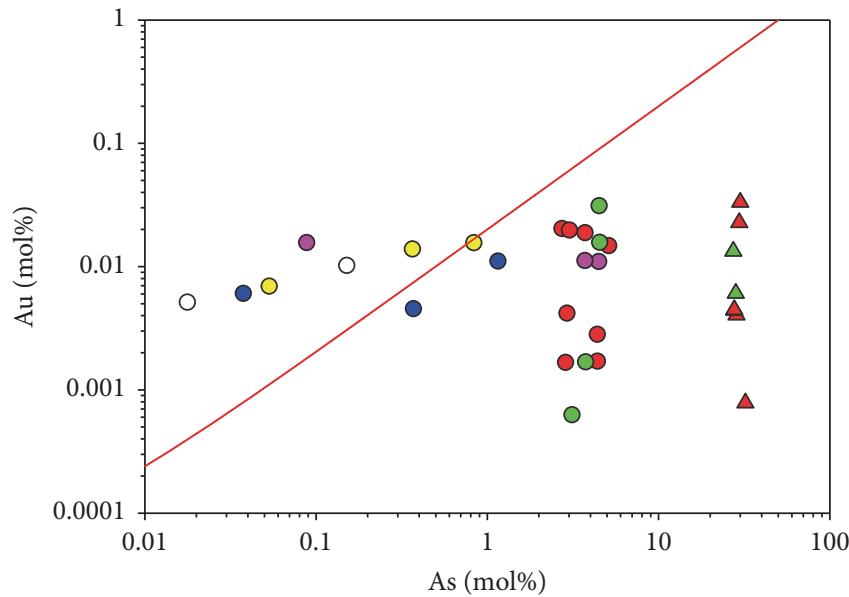

(b)

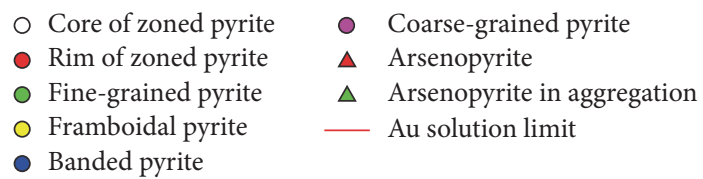

(d)

FIGURE 7: Relationships between selected elements in the arsenian pyrite and arsenopyrite, including (a) Au-Fe, (b) As-S, (c) Au-As, and (d) $\operatorname{lgAu}-\lg A s$. The red line in (d) denotes the solubility limit of Au in arsenian pyrite. The equation of the curve is $C_{\mathrm{Au}}=0.02 C_{\mathrm{As}}+4 \times 10^{-5}[11]$.

$\mathrm{Au}$ contents of the As-rich rims of zoned pyrite are much higher than in the As-poor cores. The average contents of As in the fine-grained pyrite can reach $7.3 \mathrm{wt} \%$, and this pyrite also has a relatively high $\mathrm{Au}$ content.

Previous studies have indicated that the ore-forming fluids in the study area were rich in $\mathrm{H}_{2} \mathrm{~S}[40]$ and that $\mathrm{Au}(\mathrm{HS})^{-}$ was the main material migrating in these $\mathrm{H}_{2} \mathrm{~S}$-rich fluids [48]. Interaction between As-rich hydrothermal fluids and $\mathrm{Au}(\mathrm{HS})^{-}$and $\mathrm{Fe}^{2+}$ produced by decarbonation resulted in the formation of arsenian pyrite and $\mathrm{Au}^{+}[6,26,27]$. The more that As contributes to the ore-forming process, the more that $\mathrm{Au}^{+}$enters the structure of arsenian pyrite, forming pyrite with a high Au content.

With regard to the arsenopyrite, Au was not detected at some analytical points, and it seems to be distributed heterogeneously. As a consequence, Au does not show a good correlation with As. Previous studies suggested that the iron in sulfide minerals was probably derived from the dissolution of ferroan carbonate minerals $[6,12]$. Therefore, the migration of ore-forming fluids may promote the dissolution of 


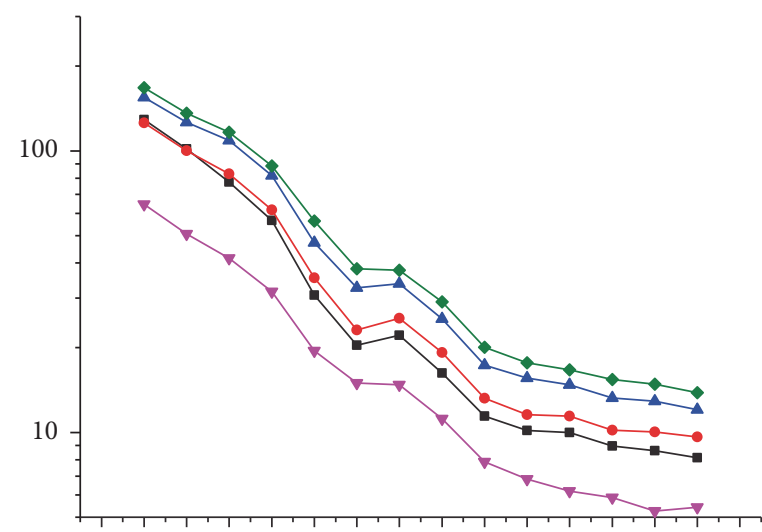

La Ce Pr Nd Sm Eu Gd Tb Dy Ho Er Tm Yb Lu

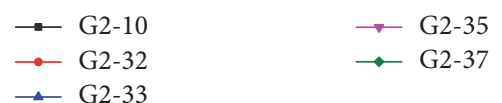

(a)

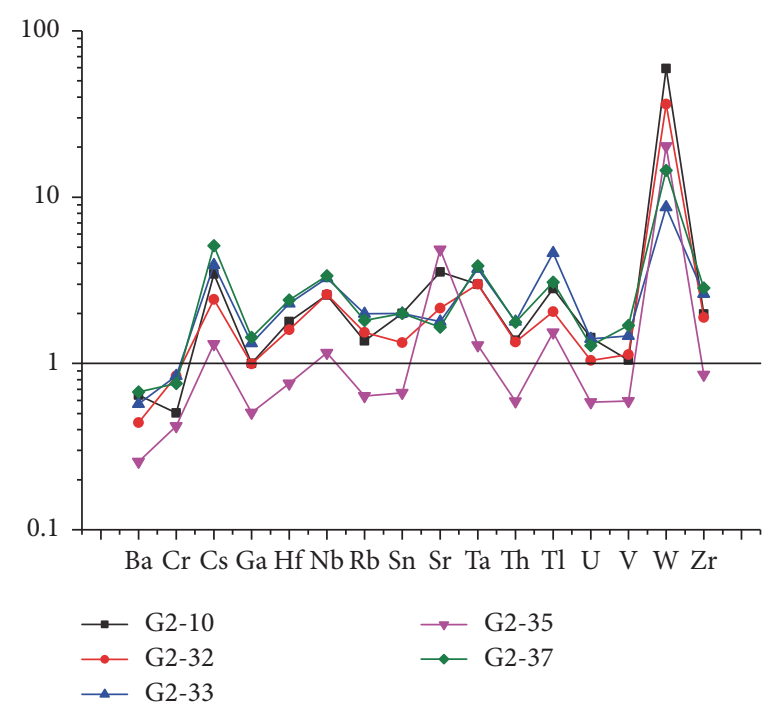

(c)

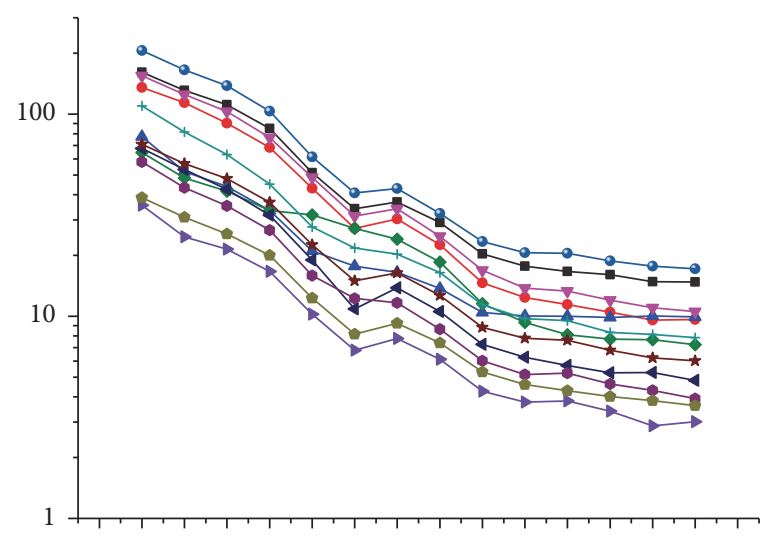

La Ce Pr Nd Sm Eu Gd Tb Dy Ho Er Tm Yb Lu

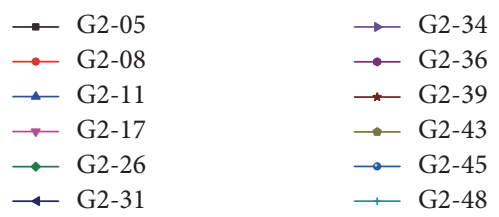

(b)

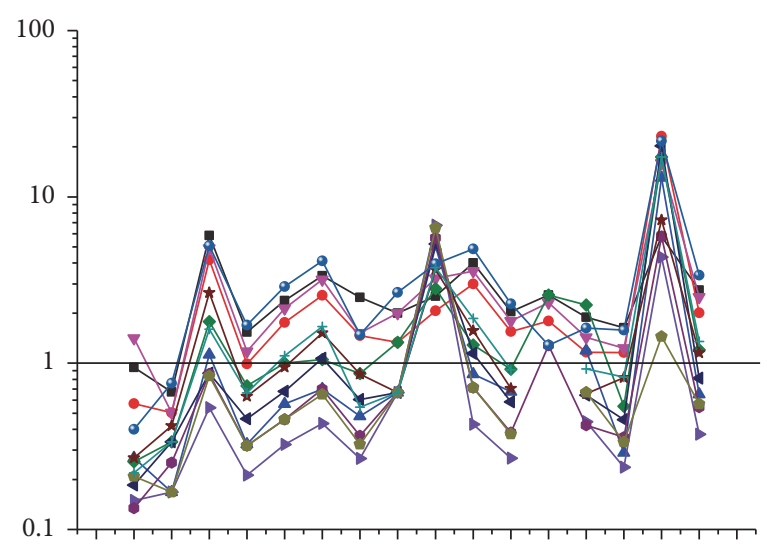

Ba Cr Cs Ga Hf Nb Rb Sn Sr Ta Th Tl U V W Zr

\begin{tabular}{|c|c|}
\hline$\rightarrow$ G2-05 & $\rightarrow \quad \mathrm{G} 2-34$ \\
\hline$\rightarrow$ G2-08 & $\rightarrow$ G2-36 \\
\hline$\multimap$ G2-11 & $\star$ G2-39 \\
\hline$\rightarrow$ G2-17 & $\rightarrow$ G2 -43 \\
\hline$\rightarrow$ G2-26 & $\rightarrow$ G2-45 \\
\hline$\simeq \mathrm{G} 2-31$ & $\rightarrow$ G2-48 \\
\hline
\end{tabular}

(d)

FIGURE 8: REE and trace element patterns or ore and wall rock in the Bojitian gold deposit. (a), (b) REE patterns of ore and wall-rock samples, respectively. (c), (d) Trace element patterns of ore and wall-rock samples, respectively.

Fe-rich carbonates, releasing more $\mathrm{Fe}^{2+}$, thus accelerating the formation of sulfide minerals. During this process, $\mathrm{Au}^{+}$may be oversaturated and form natural $\mathrm{Au}\left(\mathrm{Au}^{0}\right)[6,26,27,40]$, and this may explain why $\mathrm{Au}$ is distributed heterogeneously in the arsenopyrite. For example, in the nearby Shuiyindong deposit, the sulfides contain visible natural $\mathrm{Au}\left(\mathrm{Au}^{0}\right)$ and show a heterogeneous distribution of $\mathrm{Au}[12]$.

5.2. Occurrences of $A u$. Using the results of the EPMA point and mapping analyses, we discuss here the Au occurrences in the Bojitian deposit. Using the methods of X-ray absorption near edge structure (XANES), extended X-ray absorption fine structure (EXAFS), EPMA, and SHRIMP II, Reich et al. [11] studied the arsenian pyrite in Carlin-type and epithermal $\mathrm{Au}$ deposits and suggested a figure for the limit of $\mathrm{Au}$ solubility in the arsenian pyrite. The figure is given by the equation $C_{\mathrm{Au}}=0.02 C_{\mathrm{As}}+4 \times 10^{-5}$, where $C_{\mathrm{Au}}$ and $C_{\mathrm{As}}$ represent the molar percentages of $\mathrm{Au}$ and $\mathrm{As}$, respectively. In a diagram of $\lg A$ s versus $\lg A u$, the data that fall above the line (the limit of Au solubility) may indicate Au that exists in the form of natural nanoscale $\mathrm{Au}\left(\mathrm{Au}^{0}\right)$, while the data below the 
line may indicate Au that exists in the form of solid solution $\mathrm{Au}\left(\mathrm{Au}^{+}\right)$in the structure of arsenian pyrite.

We plotted our EPMA data for As and Au on the $\lg A s$ versus lgAu diagram (Figure $7(\mathrm{~d})$ ), and it shows that the data falling above the line are from the cores of zoned pyrite, framboidal pyrite, banded pyrite, and coarse-grained pyrite. Thus, $\mathrm{Au}$ in these pyrites may exist in the form of natural nanoscale $\mathrm{Au}\left(\mathrm{Au}^{0}\right)$. In contrast, the data falling below the line are from the rims of the zoned pyrite, the fine-grained pyrite, framboidal pyrite, banded pyrite, and coarse-grained pyrite. This suggests that $\mathrm{Au}$ in these arsenian pyrites may exist in the form of solid solution $\mathrm{Au}\left(\mathrm{Au}^{+}\right)$.

The EPMA mapping analysis yields contrasting results. As discussed above, Au in the zoned pyrite does not show the same obvious zonal structure as As, S, and Fe (Figure 5). The map shows few clear Au-rich points, indicating that $\mathrm{Au}$ exists in the form of "invisible" ultramicroscopic Au (natural nanoscale $\mathrm{Au}, \mathrm{Au}^{0}$ ).

In summary, $\mathrm{Au}$ in the cores of the zoned pyrite may exist mainly in the form of natural nanoscale $\mathrm{Au}\left(\mathrm{Au}^{0}\right)$, while the rims of the zoned pyrite mainly contain solid solution $\mathrm{Au}$ $\left(\mathrm{Au}^{+}\right)$and probably also natural nanoscale $\mathrm{Au}\left(\mathrm{Au}^{0}\right)$. The framboidal, banded, and coarse-grained pyrites contain both natural nanoscale $\mathrm{Au}\left(\mathrm{Au}^{0}\right)$ and solid solution $\mathrm{Au}\left(\mathrm{Au}^{+}\right)$.

With regard to the arsenopyrite, Au was detected at some analytical points for both single grains and aggregates of arsenopyrite and pyrite. This result may suggest that $\mathrm{Au}$ is distributed heterogeneously and that there are Au-rich areas that were incorporated into the structure of the arsenopyrite in the form of gold solution $\left(\mathrm{Au}^{+}\right)$.

5.3. Implications of the REE and Trace Element Data. REEs are widely used for determining the genesis, source, evolution, and formation of rocks. REEs can migrate within fluids, such as seawater, groundwater, and metasomatic and hydrothermal fluids, during alteration (e.g., [49-55]), and the REEs in the ores of hydrothermal deposits can be affected by the REEs in the fluids (e.g., [56-59]). Therefore, comparing the REE patterns in the ores and wall rocks may provide information on the nature of the ore-forming fluids.

The ores and wall rocks in the Bojitian deposit show similar REE patterns (Figures 8(a) and 8(b)), and both are richer in the LREEs than the HREEs, implying that the fluids that influenced the ores and wall rocks changed little over time.

$\mathrm{Ce}$ and $\mathrm{Eu}$ are commonly used to assess the sedimentary environment [60-62], and most studies indicate that if $\mathrm{Ce} / \mathrm{Ce}^{*}>1$, there is Ce enrichment that possibly reflects an oxidation environment in seawater. Values of $\mathrm{Ce} / \mathrm{Ce}^{*}<1$ may represent Ce loss at the time of precipitation of metallic oxides, indicating an anoxic reducing environment [63-65]. $\mathrm{Eu}$ is a multivalent element, occurring as $\mathrm{Eu}^{2+}$ and $\mathrm{Eu}^{3+}$. Under relatively oxidizing conditions, Eu can exist as $\mathrm{Eu}^{3+}$, and this can persist in solution for a long time. $\mathrm{Eu}^{2+}$ can be precipitated in a reducing environment, which leads to negative Eu anomalies $[7,66,67]$. In the Bojitian gold deposit, both the ore and wall-rock samples show slightly negative $\mathrm{Eu}$ anomalies, suggesting that the ore-forming fluids were from a reducing environment. However, Ce shows no apparent anomalies in the ore samples, whereas the slightly negative Ce anomalies that characterize the wall-rock samples reflect a slightly reducing environment.

Sr and W are highly enriched in both the ore and wall rock. Previous studies have suggested that $\mathrm{Sr}$ is typically enrich in hydrothermal fluids, especially in low-to-mediumtemperature fluids, whereas $\mathrm{W}$ is considered to indicate magmatic hydrothermal activity [7, 68]. In the Bojitian deposit, the enrichment in $\mathrm{Sr}$ and $\mathrm{W}$ implies that the deposit was affected by low-to-medium-temperature hydrothermal fluids, but it also indicates that magmatic hydrothermal fluids played a role in the ore-forming process. Fluid inclusions and isotopic data also testified that the ore-forming fluids of the Au deposits in the Huijiabao anticline show low-to-mediumtemperature, low salinity, and medium density with certain incorporation of magmatic hydrothermal fluids $[69,70]$.

5.4. Implications for Ore-Forming Processes. It is widely accepted that studies of Au occurrences and minerals that host $\mathrm{Au}$ in Carlin-type deposits provide not only information on the levels of Au-enrichment in different types of minerals, but also data on the distribution and content of $\mathrm{Au}$ in individual minerals, or even within one specific mineral grain. All such studies are important if we are to understand ore-forming processes. In this study we found that arsenian pyrite and arsenopyrite host $\mathrm{Au}$ and that $\mathrm{Au}$ exists mainly in the sulfides in the form of solid solution $\mathrm{Au}\left(\mathrm{Au}^{+}\right)$and natural nanoscale $\mathrm{Au}\left(\mathrm{Au}^{0}\right)$. These features also characterize the nearby Shuiyindong ultra-large Au deposit and are similar to features in other Carlin-type Au deposits, such as those in Nevada and in the "Au triangle" Shan-Gan-Chuan area of China [11, 34-38].

The similarities in the geology of these ore deposits and their gold-bearing minerals may indicate that similar ore-forming processes were responsible for all Carlin-type gold deposits in this area, including the nearby Shuiyindong deposit (Figure 9). Many studies have examined the oreforming processes of the Shuiyindong deposit. Su et al. [6] argued that Au migrated dominantly in the form of $\mathrm{Au}(\mathrm{HS})^{2-}$ and $\mathrm{AuHS}(\mathrm{aq})^{0}$ and that the dominant As species in the Shuiyindong deposit was $\mathrm{H}_{3} \mathrm{AsO}_{3}(\mathrm{aq})^{0}$. They related the formation of this deposit mainly to metamorphic fluids, but a deep magmatic component could not be excluded [6]. Chen et al. [69] suggested that the ore-forming fluids originated mainly from subsurface hydrothermal water but that some magmatic water may have been involved. Our REE and trace element data also support this inference. The most recent research also supports the idea that the formation of the Shuiyindong deposit was related to basinal fluids that migrated along faults at around $235 \pm 33 \mathrm{Ma}$ [71-73]. Comparing Shuiyindong and Bojitian, it can be seen that the occurrence of $\mathrm{Au}$ in both of these deposits is similar (dominantly as $\mathrm{Au}^{+}$in arsenian pyrite). Both deposits were also produced in the same tectonic context and in similar 


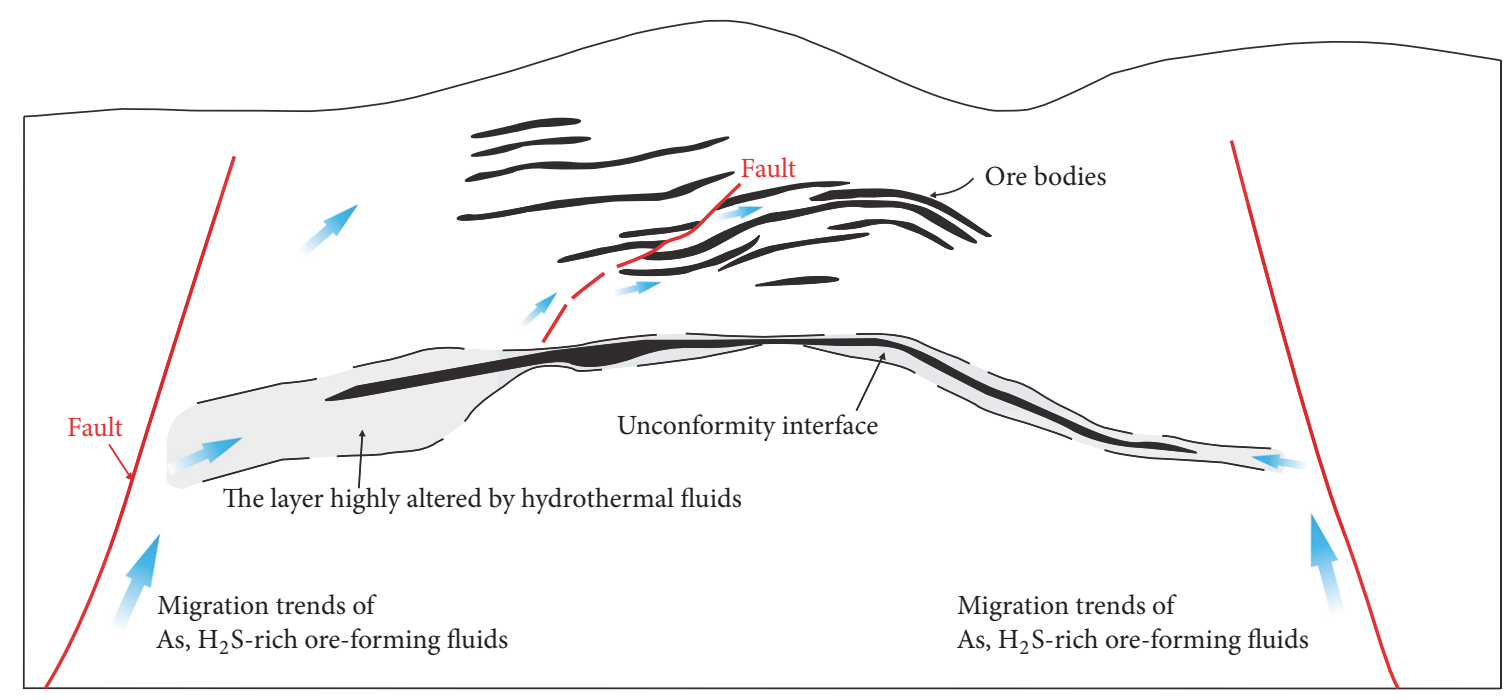

FIGURE 9: Sketch map showing the ore-forming processes in the Bojitian Carlin-type Au deposit.

strata. We infer, therefore, that the Bojitian deposit was formed via the same processes as the Shuiyindong gold deposit. The Bojitian deposit was formed from As-bearing, $\mathrm{H}_{2} \mathrm{~S}$-rich, low-to-medium-temperature fluids that migrated along faults and other channels under the influence of regional stress. Au that was already present in the strata or source beds migrated with the fluids in the form of $\mathrm{Au}(\mathrm{HS})^{-}$ and ore-forming fluids were then formed in the reducing environment. The ore-forming fluids would have interacted with Fe-rich carbonates to release large amounts of $\mathrm{Fe}^{2+}$; subsequently, $\mathrm{As}, \mathrm{Au}(\mathrm{HS})^{-}$, and $\mathrm{Fe}^{2+}$ all interacted with each other to form an abundance of arsenian sulfides. This process was accompanied by the precipitation of solid solution $\mathrm{Au}$ $\left(\mathrm{Au}^{+}\right)$and natural nanoscale $\mathrm{Au}\left(\mathrm{Au}^{0}\right)[40]$.

\section{Conclusions}

(1) Arsenian pyrite and arsenopyrite are the main Auhosting minerals in the Bojitian Carlin-type Au deposit. Zoned pyrite and fine-grained pyrite are the two major types of arsenian pyrite, followed by framboidal, coarse-grained, and banded pyrite. In addition, some pyrites fill spaces in charcoal debris that consisted of plant screen pipes or conduit rubble. All the pyrites have complex origins, and all have been affected by hydrothermal activity.

(2) $\mathrm{Au}$ is present in all five types of arsenian pyrite, but the zoned pyrite and the fine-grained pyrite are the main Au-hosting types. Both the cores and rims of the zoned pyrite contain $\mathrm{Au}$, but the rims are the main host. Individual arsenopyrite grains and aggregates of arsenopyrite and arsenian pyrite also contain $\mathrm{Au}$, with the former being the main type to host Au.

(3) $\mathrm{Au}$ in the cores of the zoned pyrite probably exists mainly in the form of natural nanoscale $\mathrm{Au}\left(\mathrm{Au}^{0}\right)$. In contrast, in the rims $\mathrm{Au}$ exists as solid solution
$\mathrm{Au}\left(\mathrm{Au}^{+}\right)$, but also probably as natural nanoscale $\mathrm{Au}$ $\left(\mathrm{Au}^{0}\right) . \mathrm{Au}$ in the framboidal, banded, and coarsegrained varieties of pyrite exists both as natural nanoscale $\mathrm{Au}\left(\mathrm{Au}^{0}\right)$ and as solid solution $\mathrm{Au}\left(\mathrm{Au}^{+}\right)$. $\mathrm{Au}$ in the arsenopyrite exists in the form of gold solution $\left(\mathrm{Au}^{+}\right)$.

(4) The Bojitian deposit was formed by As-bearing, $\mathrm{H}_{2} \mathrm{~S}$ rich, low-to-medium-temperature fluids in a reducing environment. A theoretical model for the oreforming process was developed.

\section{Conflicts of Interest}

The authors declare that they have no conflicts of interest.

\section{Acknowledgments}

The authors thank Drs. Wenchao Su and Yuping Liu from the Institute of Geochemistry, Chinese Academy of Sciences, China (Guiyang), for field work, and acknowledge the kind help of Engineer Wei Chen from the Guizhou Zijin Mining Co., Ltd., when collecting samples. This research project is supported jointly by the Natural Science Foundation of China (Grant no. 41373044), the Doctoral Program of the Ministry of Education of China (Grant no. 20130091130007), and the Independent Research Subject of State Key Laboratory for Mineral Deposits Research, Nanjing University (Grant no. ZZKT-201308).

\section{References}

[1] D. F. Hauaen and P. E. Kerr, "Fine gold occurrence at Carlin, Nevada," in Ore Desposits of the United States, J. D. Ridge, Ed., vol. 1, pp. 908-940, AIME, New York, NY, USA, 1968.

[2] A. H. Hofstra and J. S. Cline, "Characteristics and models for Carlin-type gold deposits. Reviews in Econ," Geol, vol. 19, pp. 163-220, 2000. 
[3] P. Emsbo, A. H. Hofstra, E. A. Lauha, G. L. Griffin, and R. W. Hutchinson, "Origin of high-grade gold ore, source of ore fluid components, and genesis of the Meikle and neighboring Carlintype deposits, Northern Carlin Trend, Nevada," Economic Geology, vol. 98, no. 6, pp. 1069-1100, 2003.

[4] S. E. Kesler, L. C. Riciputi, and Z. Ye, "Evidence for a magmatic origin for Carlin-type gold deposits: Isotopic composition of sulfur in the Betze-Post-Screamer Deposit, Nevada, USA," Mineralium Deposita, vol. 40, no. 2, pp. 127-136, 2005.

[5] G. Simon, S. E. Kesler, and S. Chryssoulis, "Geochemistry and textures of gold-bearing arsenian pyrite, Twin Creeks, Nevada: Implications for deposition of gold in Carlin-type deposits," Economic Geology, vol. 94, no. 3, pp. 405-421, 1999.

[6] W. Su, H. Zhang, R. Hu et al., "Mineralogy and geochemistry of gold-bearing arsenian pyrite from the Shuiyindong Carlintype gold deposit, Guizhou, China: Implications for gold depositional processes," Mineralium Deposita, vol. 47, no. 6, pp. 653662, 2012

[7] K. Liu, R. Yang, W. Chen, R. Liu, and P. Tao, “Trace element and REE geochemistry of Sanshenjiang gold deposit, southeastern Guizhou Province, China," Chinese Journal of Geochemistry, vol. 32, no. 2, pp. 212-221, 2013.

[8] X. Wu and F. Delbove, "Hydrothermal synthesis of gold-bearing arsenopyrite," Economic Geology, vol. 84, no. 7, pp. 2029-2032, 1989.

[9] M. E. Fleet, S. L. Chryssoulis, R. Davidson, C. G. Weisener, and P. J. Maclean, "Arsenian pyrite from gold deposits: Au and As distribution investigated by SIMS and EMP, and color staining and surface oxidation by XPS and LIMS," Canadian Mineralogist, vol. 31, no. 1, pp. 1-17, 1993.

[10] M. E. Fleet and A. H. Mumin, "Gold-bearing arsenian pyrite and marcasite and arsenopyrite from Carlin Trend gold deposits and laboratory synthesis," American Mineralogist, vol. 82, no. 12, pp. 182-193, 1997.

[11] M. Reich, S. E. Kesler, S. Utsunomiya, C. S. Palenik, S. L. Chryssoulis, and R. C. Ewing, "Solubility of gold in arsenian pyrite," Geochimica et Cosmochimica Acta, vol. 69, no. 11, pp. 2781-2796, 2005.

[12] W. Su, B. Xia, H. Zhang, X. Zhang, and R. Hu, "Visible gold in arsenian pyrite at the Shuiyindong Carlin-type gold deposit, Guizhou, China: Implications for the environment and processes of ore formation," Ore Geology Reviews, vol. 33, no. 3-4, pp. 667-679, 2008.

[13] T. J. Wei, "Significance on the discovery of the Carlin-type gold deposit in Guizhou," Guizhou Geol, vol. 11, pp. 269-274, 1994.

[14] C. G. Tao, "The ore-controlling condition and indicator for microfine disseminated gold deposit of southwest Guizhou," Geology and Exploration, vol. 8, pp. 9-15, 1990 (Chinese).

[15] Y. G. S. T. Wang, M. F. Suo, and Zhang M. F., Eds., Tectonics and Carlin-Type Gold Deposits in Southwestern Guizhou, Geological Publishing House, Beijing, China, 1994.

[16] W. J. Shen, Z. R. Zhang, Y. Z. Zhou, and Y. T. Lin, "Geochemistry of elements of ore-bearing rock series in the Shuiyindong gold deposit, Guizhou Province," Geochimica, vol. 34, pp. 88-95, 2005 (Chinese).

[17] S. L. He, Z. G. Zeng, M. X. Luo, Y. Z. Liu, C. L. Hu, and J. $\mathrm{Mu}$, "A review of thirty years' gold geochemical exploration in southwestern Guizhou and a prospect for future work," Geophysical and Geochemical Exploration, vol. 32, pp. 461-464, 2008 (Chinese).

[18] Y. Zhang, Y. Xia, Z. P. Wang, B. W. Yan, Z. K. Fu, and M. Chen, "REE and stable isotope geochemical characteristics of Bojitian gold deposit, Guizhou Province," Earth Sci. Front, vol. 17, pp. 385-395, 2010 (Chinese).

[19] M. C. Pan, K. Hu, J. Cao, and S. C. Han, "Gold-bearing characteristics of arsenian pyrites and arsenopyrites in the bojitian carlin-type gold deposits, Southwestern Guizhou province Southwest China," Geological Journal of China Universities, vol. 19, pp. 293-306, 2013 (Chinese).

[20] BGMRGP, "Bureau of geology and mineral resources of Guizhou province," in Regional Geology of Guizhou Province, pp. 1698, Geological Publishing House, Beijing, China, 1987.

[21] Y. Q. Cheng, Generality on Regional Geology of China, Geological Publishing House, Beijing, China, 1994.

[22] J. Z. Liu, J. H. Chen, Y. M. Deng, L. Qiu, Z. K. Fu, and F. Chen, "The implication of ZK45301 drilling hole from Shuiyindong gold deposit in Guizhou Province," Acta Mineralogica Sinica, vol. 27, pp. 448-449, 2007 (Chinese).

[23] Y. Hu, M. H. Chen, Q. J. Dong, and Q. W. Huang, “Trace elements features of the vein quartzs, arsenian pyrites and their fluid inclusions in Jinfeng (Lannigou) gold deposit, Guizhou Province," Geological Journal of China Universities, vol. 15, pp. 506-516, 2009 (Chinese).

[24] B. Hu, R. Z. Hu, C. Q. Liu, and J. Z. Liu, "Analysis on the ore-forming factors and geological characteristics of the Shuiyindong gold deposit, Southwestern Guizhou," Bulletin of Mineralogy Petrology and Geochemistry, vol. 25, pp. 141-145, 2006 (Chinese).

[25] M. Zhang, The indicative function of micro fabrics characteristics of rocks and ores to the origin of the Shuiyindong gold deposit, Guizhou University, Guizhou, China, 2008.

[26] H. T. Zhang, W. C. Su, J. J. Tian, Y. P. Liu, J. Z. Liu, and C. Q. Liu, "The occurrence of gold at Shuiyindong Carlin-type gold deposit, Guizhou," Acta Mineralogica Sinica, vol. 28, pp. 17-24, 2008 (Chinese).

[27] M. Zhang, F. Xie, Y. Tan, and Z. R. Zhang, "The indicative function of micro fabrics of rocks and ores to the origin of the Shuiyindong gold deposit," Acta Mineralogica Sinica, vol. 28, pp. 323-329, 2008 (Chinese).

[28] F. Z. Song, Geological Characteristics and Genesis of the Shuiyindong Gold Deposit, Chengdu University of Technology, Guizhou, China, 2009.

[29] J. Z. Liu, Y. Xia, Y. M. Deng et al., "Researches on the Sbt of Shuiyindong gold deposit and significance for regional prospecting," Gold Sci. Technol, vol. 17, pp. 1-5, 2009 (Chinese).

[30] C. H. Wang, D. H. Wang, J. Z. Liu et al., "Characteristics of isotopic geochemistry of Shuiyindong super-large Carlin gold deposit in Guizhou," Earth Science Frontiers, vol. 17, pp. 396403, 2010 (Chinese).

[31] Y. Xia, "Disccusion on deep prospecting for buried ore bodies and metallogenic mechanism of stratabound carlin-type gold deposit, Southwestern Guizhou Province, China," Acta Mineralogica Sinica, vol. 27, pp. 532-533, 2007 (Chinese).

[32] M. H. Chen, J. W. Mao, Z. Y. Chen, and W. Zhang, "Mineralogy of arsenian pyrites and arsenopyrites of Carlin-type gold deposits in Yunnan-Guizhou-Guangxi, "golden triangle" area, southwestern China," Miner. Deposits, vol. 28, pp. 539-557, 2009 (Chinese).

[33] J. Z. Liu, J. H. Chen, Y. M. Deng et al., "Exploration of the Shuiyingdong super-scale gold deposit and the evolution of exploration for metallogenic belt of the Huijiabao anticline in Guizhou Province," Geological Survey and Research, vol. 32, pp. 138-143, 2009 (Chinese). 
[34] C. S. Palenik, S. Utsunomiya, M. Reich, S. E. Kesler, L. Wang, and R. C. Ewing, "“Invisible" gold revealed: direct imaging of gold nanoparticles in a Carlin-type deposit," American Mineralogist, vol. 89, no. 10, pp. 1359-1366, 2004.

[35] A. Cepedal, M. Fuertes-Fuente, A. Martin-Izard, S. GonzálezNistal, and M. Barrero, "Gold-bearing As-rich pyrite and arsenopyrite from the El Valle gold deposit, Asturias, northwestern Spain," Canadian Mineralogist, vol. 46, no. 1, pp. 233247, 2008.

[36] S. L. L. Barker, K. A. Hickey, J. S. Cline et al., "Uncloaking invisible gold: use of NanoSIMS to evaluate gold, trace elements, and sulfur isotopes in pyrite from Carlin-type gold deposits," Economic Geology, vol. 104, no. 7, pp. 897-904, 2009.

[37] C. M. De Almeida, G. R. Olivo, A. Chouinard, C. Weakly, and G. Poirier, "Mineral paragenesis, alteration, and geochemistry of the two types of gold ore and the host rocks from the carlintype deposits in the southern part of the Goldstrike Property, Northern Nevada: implications for sources of ore-forming elements, ore genesis, and mineral exploration," Economic Geology, vol. 105, no. 5, pp. 971-1004, 2010.

[38] H. Z. Lu, X. Q. Zhu, Q. Shan, and Z. G. Wang, "Hydrothermal evolution of gold-bearing pyrite and arsenopyrite from different types of gold deposits," Miner. Deposits, vol. 32, pp. 823-842, 2013 (Chinese).

[39] S.-S. Sun and W. F. McDonough, "Chemical and isotopic systematics of oceanic basalts: implications for mantle composition and processes," Geological Society Special Publication, vol. 42, no. 1, pp. 313-345, 1989.

[40] W. Su, R. Hu, B. Xia, Y. Xia, and Y. Liu, "Calcite Sm-Nd isochron age of the Shuiyindong Carlin-type gold deposit, Guizhou, China," Chemical Geology, vol. 258, no. 3-4, pp. 269-274, 2009.

[41] J. Z. Liu, Y. Xia, Y. M. Deng, X. C. Zhang, and L. Qiu, "b. Restudy on modes of gold occurrence in the Shuiyindong superlarge-sized glod deposit," Guizhou Geol, vol. 24, pp. 165-169, 2007 (Chinese).

[42] L. Z. Zhang and X. Z. Cao, "Typomorphic characteristics of pyrite from Shuiyindong gold deposit in Guizhou Province," Contributions to Geology and Mineral Resources Research, vol. 25, pp. 101-106, 2010 (Chinese).

[43] A. K. Cakrabarti, "On the trace etement geochemistry of zawar sulphides and its relation to metallogenesis," The Canadian Mineralogist, vol. 9, pp. 258-262, 1967.

[44] G. Loftus-Hills and M. Solomon, "Cobalt, nickel and selenium in sulphides as indicators of ore genesis," Mineralium Deposita, vol. 2, no. 3, pp. 228-242, 1967.

[45] X. Z. Wang, J. P. Chen, B. G. Zhang, W. L. Fan, H. Bai Z, and H. Y. Liang, Geochemistry of the Reforming Type of Gold Deposits in China, Science Press, Beijing, China, 1992.

[46] A. Kumar, A. S. Venkatesh, P. V. R. Amesh Babu, and S. Nayak, "Genetic implications of rare uraninite and pyrite in quartzpebble conglomerates from Sundargarh District of Orissa, Eastern India," Journal of the Geological Society of India, vol. 79, no. 3, pp. 279-286, 2012.

[47] A. P. Deditius, S. Utsunomiya, D. Renock et al., "A proposed new type of arsenian pyrite: composition, nanostructure and geological significance," Geochimica et Cosmochimica Acta, vol. 72, no. 12, pp. 2919-2933, 2008.

[48] T. M. Seward, "Thio complexes of gold and the transport of gold in hydrothermal ore solutions," Geochimica et Cosmochimica Acta, vol. 37, no. 3, pp. 379-399, 1973.
[49] S. M. McLennan and S. R. Taylor, "Rare earth element mobility associated with uranium mineralisation," Nature, vol. 282, article 5736, pp. 247-250, 1979.

[50] H. W. Nesbitt, "Mobility and fractionation of rare earth elements during weathering of a granodiorite," Nature, vol. 279, pp. 206-210, 1979.

[51] D. H. M. Alderton, J. A. Pearce, and P. J. Potts, "Rare earth element mobility during granite alteration: evidence from southwest England," Earth and Planetary Science Letters, vol. 49, no. 1, pp. 149-165, 1980.

[52] S. E. Humphris, "The mobility of the rare earth elements in the crust.," Rare Earth Element Geochemistry, pp. 317-342, 1983.

[53] D. J. Whitford, M. J. Korsch, P. M. Porritt, and S. J. Craven, "Rare-earth element mobility around the volcanogenic polymentallic massive sulfide deposit at Que River, Tasmania, Australia," Chemical Geology, vol. 68, no. 1-2, pp. 105-119, 1988.

[54] L. Raimbault, A. Baumer, M. Dubru, C. Benkerrou, V. Croze, and A. Zahm, "REE fractionation between scheelite and apatite in hydrothermal conditions," American Mineralogist, vol. 78, no. 11-12, pp. 1275-1285, 1993.

[55] M. P. Smith, P. Henderson, and L. S. Campbell, "Fractionation of the REE during hydrothermal processes: Constraints from the Bayan Obo Fe-REE-Nb deposit, Inner Mongolia, China," Geochimica et Cosmochimica Acta, vol. 64, no. 18, pp. 3141-3160, 2000.

[56] M. Bau, "Rare-earth element mobility during hydrothermal and metamorphic fluid-rock interaction and the significance of the oxidation state of europium," Chemical Geology, vol. 93, no. 3-4, pp. 219-230, 1991.

[57] Z. J. Ding, S. Z. Yao, C. Q. Liu, Z. G. Zhou, and M. G. Yang, "The characteristics of exhalation-sedimentary deposit of Donggouba polymetal deposit: evidence from ores REE composition," Acta Petrologica Sinica, vol. 19, article 792798, Article ID 792798, 2003 (Chinese).

[58] M. H. Chen, L. L. Wu, P. J. Uttley, T. Norman, J. M. Zheng, and Y. Z. Qin, "REE features of arseuian pyrite and vein quartz and their fluid inclusions in the Jinfeng (Lannigou) gold deposit, Guizhou province," Acta Petrologica Sinica, vol. 23, pp. 24232433, 2007 (Chinese).

[59] D. Chetty and J. Gutzmer, "REE redistribution during hydrothermal alteration of ores of the Kalahari Manganese Deposit," Ore Geology Reviews, vol. 47, pp. 126-135, 2012.

[60] H. J. W. De Baar, M. P. Bacon, P. G. Brewer, and K. W. Bruland, "Rare earth elements in the Pacific and Atlantic Oceans," Geochimica et Cosmochimica Acta, vol. 49, no. 9, pp. 1943-1959, 1985.

[61] H. J. W. de Baar, C. R. German, H. Elderfield, and P. van Gaans, "Rare earth element distributions in anoxic waters of the Cariaco Trench," Geochimica et Cosmochimica Acta, vol. 52, no. 5, pp. 1203-1219, 1988.

[62] C. R. German and H. Elderfield, "Application of the Ce anomaly as a paleoredox indicator: The ground rules," Paleoceanography, vol. 5, no. 5, pp. 823-833, 1990.

[63] X. L. Yang, M. Y. Zhu, Y. L. Zhao, J. M. Zhang, Q. J. Guo, and D. $\mathrm{H}$. Pi, "REE geochemical characteristics of the ediacaran-lower cambrian black rock series in eastern Guizhou," Geological Rev, vol. 54, pp. 3-15, 2008 (Chinese).

[64] X. C. Xu, W. J. Wang, Y. P. Xiong, P. L. Chu, H. B. Fang, and L. L. Zhao, "REE geochemical characteristics of the Lower Cambrian black shale series in Shitai area, Anhui Province, and their geological significance," Acta Petrol. Mineral, vol. 28, pp. 118128, 2009 (Chinese). 
[65] G. B. Qiao, Z. T. Yang, Z. M. Li, X. Y. Yang, and X. H. Lan, "REE geochemical characteristics of the Cambrian carbonaceous rock series in the Mian-Liie region and their genetical implications," Journal of Jilin University (Earth Science Edition), vol. 41, pp. 1067-1076, 2011 (Chinese).

[66] Z. G. Wang, Rare Earth Element Geochemistry, Science Press, Beijing, China, 1989.

[67] F. Li, "Rare earth element geochemistry of the Dapingzhang Cu-polymetallic deposit in western Yunnan," Acta Petrologica et Mineralogica, vol. 22, pp. 259-264, 2003 (Chinese).

[68] R. Yang, X. Zhang, L. Liu, S. Yuan, and L. Xu, "Geochemical characteristics of REE and trace element: Implication for gold source in the Xiajiang Group of neoproterozoic qingbaikouan system, Jinping county, Guizhou Province, China," Acta Geologica Sinica, vol. 83, no. 4, pp. 505-514, 2009.

[69] B. J. Chen, C. Q. Wen, Y. Huo, S. Y. Cao, F. Z. Song, and Y. Zhong, "Study on fluid inclusion of the Shuiyindong gold deposit, Southwestern Guizhou," Bulletin of Mineralogy Petrology and Geochemistry, vol. 29, pp. 45-51, 2010 (Chinese).

[70] B. H. Li, X. X. Gu, S. H. Fu, S. H. Xu, C. H. Chen, and S. Y. Dong, "The evidence from fluid inclusions for the immiscibility of the ore-forming fluids in the Shuiyindong gold deposit Guizhou Province," Earth Science Frontiers, vol. 17, pp. 286-294, 2010 (Chinese).

[71] M. Chen, Z. Zhang, M. Santosh, Y. Dang, and W. Zhang, "The Carlin-type gold deposits of the "golden triangle" of SW China: $\mathrm{Pb}$ and $\mathrm{S}$ isotopic constraints for the ore genesis," Journal of Asian Earth Sciences, vol. 103, no. 1, pp. 115-128, 2015.

[72] M. Chen, J. Mao, C. Li, Z. Zhang, and Y. Dang, "Re-Os isochron ages for arsenopyrite from Carlin-like gold deposits in the Yunnan-Guizhou-Guangxi "golden triangle", southwestern China,” Ore Geology Reviews, vol. 64, no. 1, pp. 316-327, 2015.

[73] Q.-P. Tan, Y. Xia, Z.-J. Xie, and J. Yan, "Migration paths and precipitation mechanisms of ore-forming fluids at the Shuiyindong Carlin-type gold deposit, Guizhou, China," Ore Geology Reviews, vol. 69, pp. 140-156, 2015. 

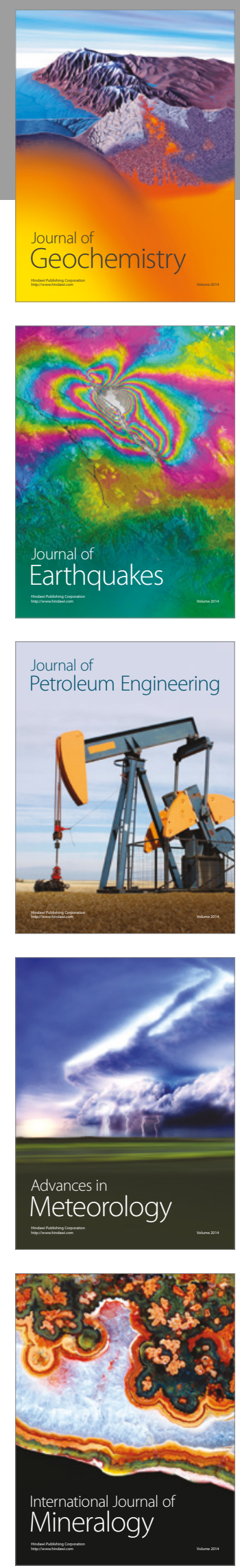
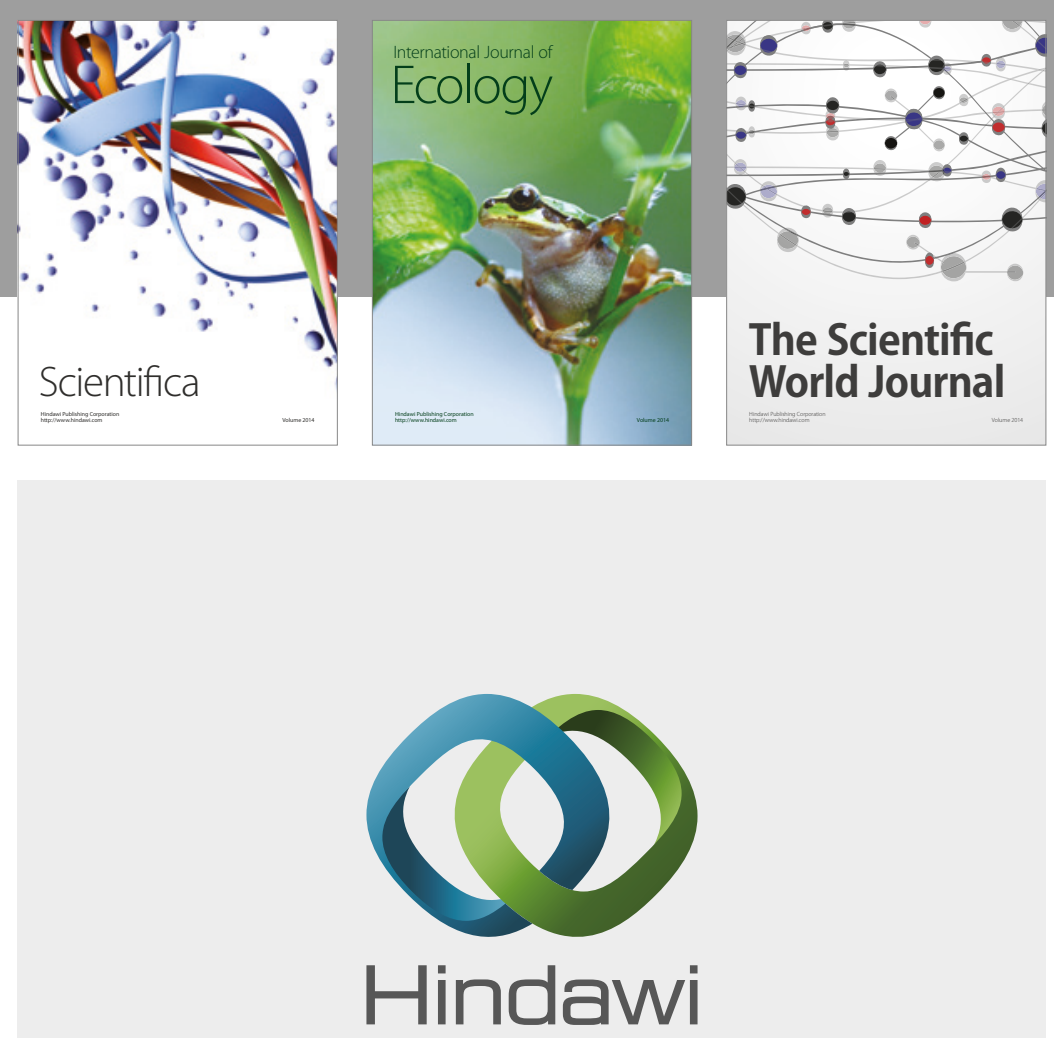

Submit your manuscripts at

https://www.hindawi.com
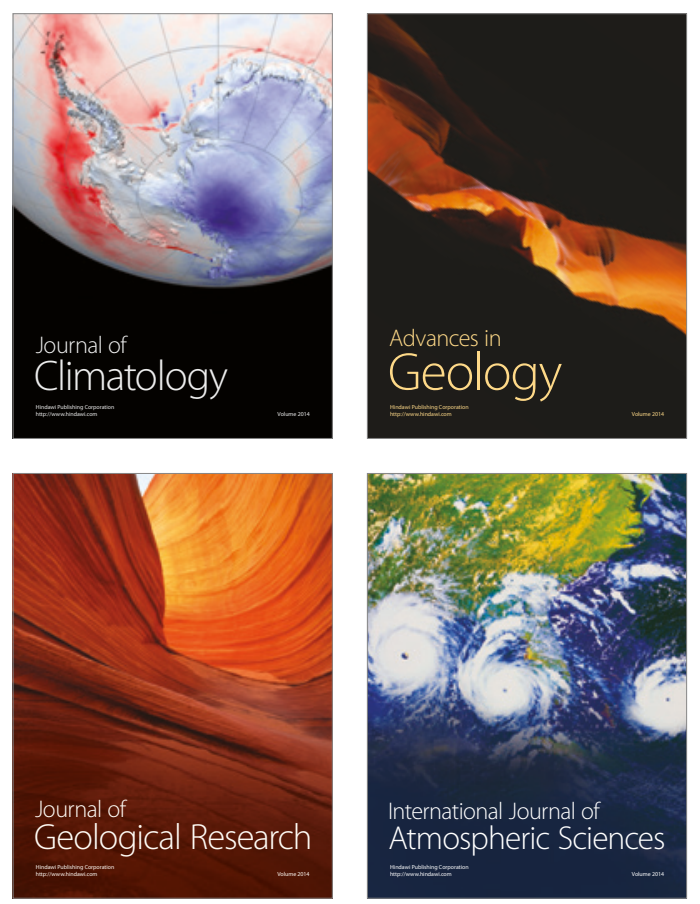

The Scientific

World Journal
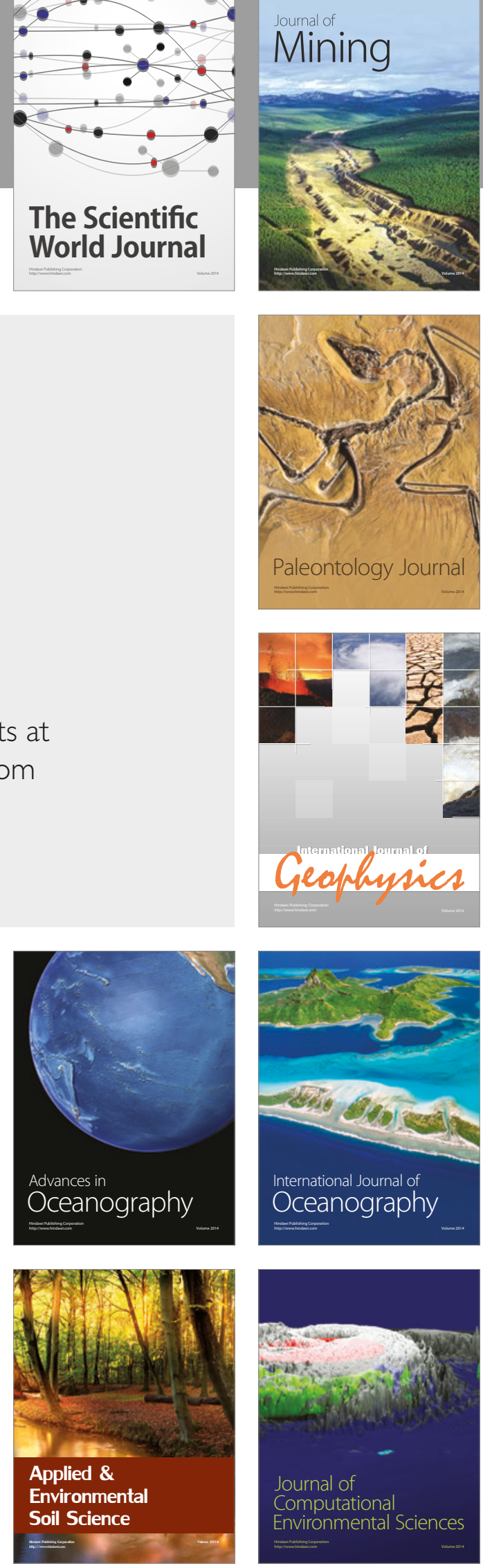